4

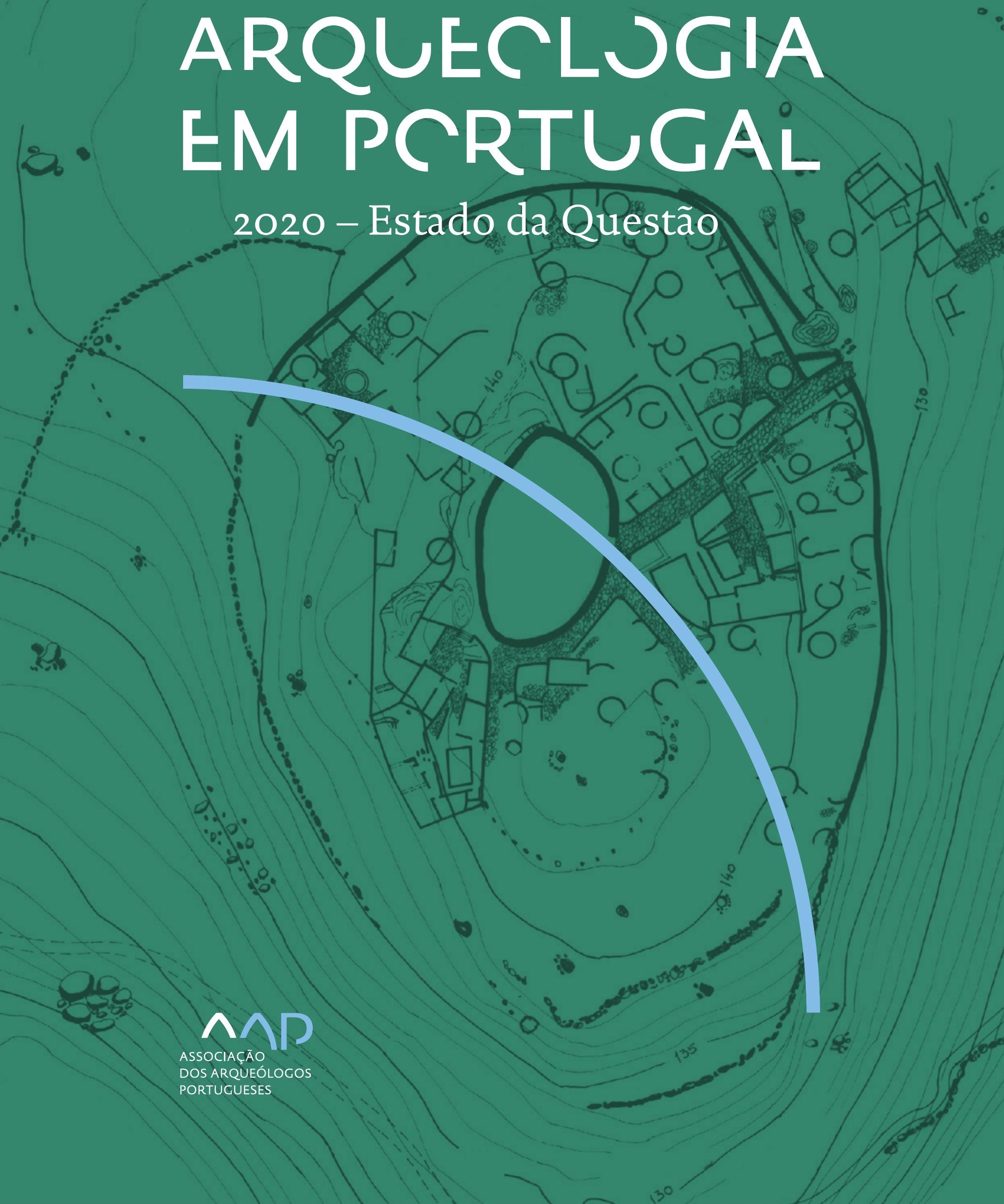


Coordenação editorial: José Morais Arnaud, César Neves e Andrea Martins Design gráfico: Flatland Design

AAP - ISBN: 978-972-9451-89-8

CITCEM - ISBN: 978-989-8970-25-1

Associação dos Arqueólogos Portugueses e CITCEM

Lisboa, 2020

O conteúdo dos artigos é da inteira responsabilidade dos autores. Sendo assim a Associação dos Arqueólogos Portugueses declina qualquer responsabilidade por eventuais equívocos ou questões de ordem ética e legal.

Desenho de capa:

Planta do castro de Monte Mozinho (Museu Municipal de Penafiel).

\section{$\hat{\wedge} \mathrm{P}$}

DOS ARQUEÓLOGOS PORTUGUESES

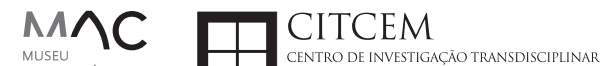
MUSEU
ARQUELLÓGICO
DO CARMO
U.PORTO

FLUP FACULDADE DE LETRAS
UNIVERSIDADE DO PORTO

Apoio

EC para a Ciência 


\section{Índice}

15 Prefácio

José Morais Arnaud

\section{Historiografia e Teoria}

17 Território, comunidade, memória e emoção: a contribuição da história da arqueologia (algumas primeiras e breves reflexões)

Ana Cristina Martins

25 Como descolonizar a arqueologia portuguesa?

Rui Gomes Coelho

41 Arqueologia e Modernidade: uma revisitação pessoal e breve de alguns aspetos da obra homónima de Julian Thomas de 2004

Vítor Oliveira Jorge

57 Dados para a História das Mulheres na Arqueologia portuguesa, dos finais do século XIX aos inícios do século XX: números, nomes e tabelas

Filipa Dimas / Mariana Diniz

73 Retractos da arqueologia portuguesa na imprensa: (in)visibilidades no feminino

Catarina Costeira / Elsa Luís

85 Arqueologia e Arqueólogos no Norte de Portugal Jacinta Bugalhão

101 Vieira Guimarães (1864-1939) e a arqueologia em Tomar: uma abordagem sobre o território e as gentes

João Amendoeira Peixoto / Ana Cristina Martins

115 Os memoráveis? A arqueologia algarvia na imprensa nacional e regional na presente centúria (2001-2019): características, visões do(s) passado(s) e a arqueologia

enquanto marca

Frederico Agosto / João Silva

129 A Evolução da Arqueologia Urbana e a Valorização Patrimonial no Barlavento Algarvio: Os casos de Portimão e Silves

Artur Mateus / Diogo Varandas / Rafael Boavida

\section{Gestão, Valorização e Salvaguarda do Património}

145 O Caderno Reivindicativo e as condições de trabalho em Arqueologia Miguel Rocha / Liliana Matias Carvalho / Regis Barbosa / Mauro Correia / Sara Simões / Jacinta Bugalhão / Sara Brito / Liliana Veríssimo Carvalho / Richard Peace / Pedro Peça / Cézer Santos

155 Os Estudos de Impacte Patrimonial como elemento para uma estratégia sustentável de minimização de impactes no âmbito de reconversões agrícolas Tiago do Pereiro

165 Salvaguarda de Património arqueológico em operações florestais: gestão e sensibilização Filipa Bragança / Gertrudes Zambujo / Sandra Lourenço / Belém Paiva / Carlos Banha / Frederico Tatá Regala / Helena Moura / Jacinta Bugalhão / João Marques / José Correia / Pedro Faria / Samuel Melro

179 Os valores do Património: uma investigação sobre os Sítios Pré-históricos de Arte Rupestre do Vale do Rio Côa e de Siega Verde José Paulo Francisco 
189 Conjugando recursos arqueológicos e naturais para potenciar as visitas ao Geoparque Litoral de Viana do Castelo (Noroeste de Portugal)

Hugo A. Sampaio / Ana M.S. Bettencourt / Susana Marinho / Ricardo Carvalhido

203 Áreas de Potencial Arqueológico na Região do Médio Tejo: Modelo Espacial Preditivo Rita Ferreira Anastácio / Ana Filipa Martins / Luiz Oosterbeek

223 Património Arqueológico e Gestão Territorial: O contributo da Arqueologia para a revisão do PDM de Avis

Ana Cristina Ribeiro

237 A coleção arqueológica do extinto Museu Municipal do Porto - Origens, Percursos e Estudos

Sónia Couto

251 Valpaços - uma nova carta arqueológica

Pedro Pereira / Maria de Fátima Casares Machado

263 Arqueologia na Cidade de Peniche

Adriano Constantino / Luís Rendeiro

273 Arqueologia Urbana: a cidade de Lagos como caso de Estudo Cátia Neto

285 Estratégias de promoção do património cultural subaquático nos Açores. O caso da ilha do Faial

José Luís Neto / José Bettencourt / Luís Borges / Pedro Parreira

297 Carta Arqueológica da Cidade Velha: Uma primeira abordagem

Jaylson Monteiro / Nireide Tavares / Sara da Veiga / Claudino Ramos / Edson Brito /

Carlos Carvalho / Francisco Moreira / Adalberto Tavares

311 Antropologia Virtual: novas metodologias para a análise morfológica e funcional Ricardo Miguel Godinho / Célia Gonçalves

\section{Didáctica da Arqueologia}

327 Como os projetos de Arqueologia podem contribuir para uma comunidade culturalmente mais consciente Alexandra Figueiredo / Claúdio Monteiro / Adolfo Silveira / Ricardo Lopes

337 Educação Patrimonial - Um cidadão esclarecido é um cidadão ativo! Ana Paula Almeida

351 A aproximação da Arqueologia à sala de aula: um caso de estudo no $3^{\circ}$ ciclo do Ensino Básico Luís Serrão Gil

363 Arqueologia 3.o - Pensar e comunicar a Arqueologia para um futuro sustentável Mónica Rolo

377 “Conversa de Arqueólogos" - Divulgar a Arqueologia em tempos de Pandemia Diogo Teixeira Dias

389 Escola Profissional de Arqueologia: desafios e oportunidades Susana Nunes / Dulcineia Pinto / Júlia Silva / Ana Mascarenhas

399 Os Museus de Arqueologia e os Jovens: a oferta educativa para o público adolescente Beatriz Correia Barata / Leonor Medeiros

411 O museu universitário como mediador entre a ciência e a sociedade: o exemplo da secção de arqueologia no Museu de História Natural e da Ciência da Universidade do Porto (MHNC-UP)

Rita Gaspar 
421 Museu de Lanifícios: Real Fábrica de Panos. Atividades no âmbito da Arqueologia Beatriz Correia Barata / Rita Salvado

427 Arqueologia Pública e o caso da localidade da Mata (Torres Novas) Cláudia Manso / Ana Rita Ferreira / Cristiana Ferreira / Vanessa Cardoso Antunes

431 Do sítio arqueológico ao museu: um percurso (também) didático Lídia Fernandes

447 Estão todos convidados para a Festa! E para dançar também... O projecto do Serviço Educativo do Museu Arqueológico do Carmo na $5^{\underline{a}}$ Edição da Festa da Arqueologia Rita Pires dos Santos

459 O “Clã de Carenque”, um projeto didático de arqueologia Eduardo Gonzalez Rocha

469 Mediação cultural: peixe que puxa carroça nas Ruínas Romanas de Troia Inês Vaz Pinto / Ana Patrícia Magalhães / Patrícia Brum / Filipa Santos

481 Didática Arqueológica, experiências do Projeto Mértola Vila Museu Maria de Fátima Palma / Clara Rodrigues / Susana Gómez / Lígia Rafael

\section{Arte Rupestre}

497 Os inventários de arte rupestre em Portugal Mila Simões de Abreu

513 O projeto FIRST-ART - conservação, documentação e gestão das primeiras manifestações de arte rupestre no Sudoeste da Península Ibérica: as grutas do Escoural e Maltravieso Sara Garcês / Hipólito Collado / José Julio García Arranz / Luiz Oosterbeek / António Carlos Silva / Pierluigi Rosina / Hugo Gomes / Anabela Borralheiro Pereira / George Nash / Esmeralda Gomes / Nelson Almeida / Carlos Carpetudo

523 Trabalhos de documentação de arte paleolítica realizados no âmbito do projeto PalæoCôa André Tomás Santos / António Fernando Barbosa / Luís Luís / Marcelo Silvestre / Thierry Aubry

537 Imagens fantasmagóricas, silhuetas elusivas: as figuras humanas na arte do Paleolítico Superior da região do Côa Mário Reis

$55^{1}$ Os motivos zoomórficos representados nas placas de tear de Vila Nova de São Pedro (Azambuja, Portugal) Andrea Martins / César Neves / José M. Arnaud / Mariana Diniz

571 Arte Rupestre do Monte de Góios (Lanhelas, Caminha). Síntese dos resultados dos trabalhos efectuados em 2007-2009 Mário Varela Gomes

599 Gravuras rupestres de barquiformes no Monte de S. Romão, Guimarães, Noroeste de Portugal Daniela Cardoso

613 Círculos segmentados gravados na Bacia do Rio Lima (Noroeste de Portugal): contributos para o seu estudo Diogo Marinho / Ana M.S. Bettencourt / Hugo Aluai Sampaio

631 Equídeos gravados no curso inferior do Rio Mouro, Monção (NW Portugal). Análise preliminar Coutinho, L.M. / Bettencourt, A.M.S / Sampaio, Hugo A.S

645 Paletas na Arte Rupestre do Noroeste de Portugal. Inventário preliminar Bruna Sousa Afonso / Ana M. S. Bettencourt / Hugo A. Sampaio 


\section{Pré-História}

661 O projeto Miño/Minho: balanço de quatro anos de trabalhos arqueológicos Sérgio Monteiro-Rodrigues / João Pedro Cunha-Ribeiro / Eduardo Méndez-Quintas / Carlos Ferreira / Pedro Xavier / José Meireles / Alberto Gomes / Manuel Santonja / Alfredo Pérez-González

677 A ocupação paleolítica da margem esquerda do Baixo Minho: a indústria lítica do sítio de Pedreiras 2 (Monção, Portugal) e a sua integração no contexto regional Carlos Ferreira / João Pedro Cunha-Ribeiro / Sérgio Monteiro-Rodrigues / Eduardo Méndez-Quintas / Pedro Xavier / José Meireles / Alberto Gomes / Manuel Santonja / Alfredo Pérez-González

693 O sítio acheulense do Plistocénico médio da Gruta da Aroeira Joan Daura / Montserrat Sanz / Filipa Rodrigues / Pedro Souto / João Zilhão

703 As sociedades neandertais no Barlavento algarvio: modelos preditivos com recurso aos SIG

Daniela Maio

715 A utilização de quartzo durante o Paleolítico Superior no território dos vales dos rios Vouga e Côa

Cristina Gameiro / Thierry Aubry / Bárbara Costa / Sérgio Gomes / Luís Luís / Carmen Manzano / André Tomás Santos

733 Uma perspetiva diacrónica da ocupação do concheiro do Cabeço da Amoreira (Muge, Portugal) a partir da tecnologia lítica Joana Belmiro / João Cascalheira / Célia Gonçalves

745 Novos dados sobre a Pré-história Antiga no concelho de Palmela. A intervenção arqueológica no sítio do Poceirão I

Michelle Teixeira Santos

757 Problemas em torno de Datas Absolutas Pré-Históricas no Norte do Alentejo Jorge de Oliveira

771 Povoamento pré-histórico nas áreas montanhosas do NO de Portugal: o Abrigo 1 de Vale de Cerdeira Pedro Xavier / José Meireles / Carlos Alves

783 Apreciação do povoamento do Neolítico Inicial na Baixa Bacia do Douro. A Lavra I (Serra da Aboboreira) como caso de estudo Maria de Jesus Sanches

797 O Processo de Neolitização na Plataforma do Mondego: os dados do Sector C do Outeiro dos Castelos de Beijós (Carregal do Sal)

João Carlos de Senna-Martinez / José Manuel Quintã Ventura / Andreia Carvalho / Cíntia Maurício

823 Novos trabalhos na Lapa da Bugalheira (Almonda, Torres Novas) Filipa Rodrigues / Pedro Souto / Artur Ferreira / Alexandre Varanda / Luís Gomes / Helena Gomes / João Zilhão

837 A pedra polida e afeiçoada do sítio do Neolítico médio da Moita do Ourives (Benavente, Portugal)

César Neves

857 Casal do Outeiro (Encarnação, Mafra): novos contributos para o conhecimento do povoamento do Neolítico final na Península de Lisboa.

Cátia Delicado / Carlos Maneira e Costa / Marta Miranda / Ana Catarina Sousa

873 Stresse infantil, morbilidade e mortalidade no sítio arqueológico do Neolítico Final/ Calcolítico ( $4^{\circ}$ e $3^{\circ}$ milénio a.C.) do Monte do Carrascal 2 (Ferreira do Alentejo, Beja) Liliana Matias de Carvalho / Sofia N. Wasterlain 
885 Come together: O Conjunto Megalítico das Motas (Monção, Viana do Castelo) e as expressões Campaniformes do Alto Minho Ana Catarina Basílio / Rui Ramos

899 Trabalhos arqueológicos no sítio Calcolítico da Pedreira do Poio Carla Magalhães / João Muralha / Mário Reis / António Batarda Fernandes

913 O sítio arqueológico de Castanheiro do Vento. Da arquitectura do sítio à arquitectura de um território João Muralha Cardoso

925 Estudo zooarqueológico das faunas do Calcolítico final de Vila Nova de São Pedro (Azambuja, Portugal): Campanhas de 2017 e 2018 Cleia Detry / Ana Catarina Francisco / Mariana Diniz / Andrea Martins / César Neves / José Morais Arnaud

943 As faunas depositadas no Museu Arqueológico do Carmo provenientes de Vila Nova de São Pedro (Azambuja): as campanhas de 1937 a 1967 Ana Catarina Francisco / Cleia Detry / César Neves / Andrea Martins / Mariana Diniz / José Morais Arnaud

959 Análise funcional de material lítico em sílex do castro de Vila Nova de S. Pedro (Azambuja, Portugal): uma primeira abordagem Rafael Lima

971 O recinto da Folha do Ouro 1 (Serpa) no contexto dos recintos de fossos calcolíticos alentejanos

António Carlos Valera / Tiago do Pereiro / Pedro Valério / António M. Monge Soares

\section{Proto-História}

987 Produção de sal marinho na Idade do Bronze do noroeste Português. Alguns dados para uma reflexão

Ana M. S. Bettencourt / Sara Luz / Nuno Oliveira / Pedro P. Simões / Maria Isabel C. Alves / Emílio Abad-Vidal

1001 A estátua-menir do Pedrão ou de São Bartolomeu do Mar (Esposende, noroeste de Portugal) no contexto arqueológico da fachada costeira de entre os rios Neiva e Cávado Ana M. S. Bettencourt / Manuel Santos-Estévez / Pedro Pimenta Simões / Luís Gonçalves

1015 O Castro do Muro (Vandoma/Baltar, Paredes) - notas para uma biografia de ocupação da Idade do Bronze à Idade Média

Maria Antónia D. Silva / Ana M. S. Bettencourt / António Manuel S. P. Silva / Natália Félix

1031 Do Bronze Final à Idade Média - continuidades e hiatos na ocupação de Povoados em Oliveira de Azeméis João Tiago Tavares / Adriaan de Man

1041 As faunas do final da Idade do Bronze no Sul de Portugal: leituras desde o Outeiro do Circo (Beja)

Nelson J. Almeida / Íris Dias / Cleia Detry / Eduardo Porfírio / Miguel Serra

1055 A Espada do Monte das Oliveiras (Serpa) - uma arma do Bronze Pleno do Sudoeste Rui M. G. Monge Soares / Pedro Valério / Mariana Nabais / António M. Monge Soares

1065 São Julião da Branca (Albergaria-a-Velha) - Investigação e valorização de um povoado do Bronze Final

António Manuel S. P. Silva / Paulo A. P. Lemos / Sara Almeida e Silva / Edite Martins de Sá

1083 Do castro de S. João ao Mosteiro de Santa Clara: notícia de uma intervenção arqueológica, em Vila do Conde Rui Pinheiro 
1095 O castro de Ovil (Espinho), um quarto de século de investigação - resultados e questões em aberto

Jorge Fernando Salvador / António Manuel S. P. Silva

1111 O Castro de Salreu (Estarreja), um povoado proto-histórico no litoral do Entre Douro e Vouga

Sara Almeida e Silva / António Manuel S. P. Silva / Paulo A. P. Lemos / Edite Martins de Sá

1127 Castro de Nossa Senhora das Necessidades (Sernancelhe): uma primeira análise artefactual Telma Susana O. Ribeiro

${ }_{1141}$ A cividade de Bagunte. O estado atual da investigação Pedro Brochado de Almeida

1153 Zoomorfos na cerâmica da Idade do Ferro no NW Peninsular: inventário, cronologias e significado Nuno Oliveira / Cristina Seoane

1163 Vasos gregos em Portugal: diferentes maneiras de contar a história do intercâmbio cultural na Idade do Ferro

Daniela Ferreira

1175 Os exotica da necrópole da Idade do Ferro do Olival do Senhor dos Mártires (Alcácer do Sal) no seu contexto regional

Francisco B. Gomes

\section{Antiguidade Clássica e Tardia}

1191 O uso de madeira como combustível no sítio da Quinta de Crestelos (Baixo Sabor): da Idade do Ferro à Romanização Filipe Vaz / João Tereso / Sérgio Simões Pereira / José Sastre / Javier Larrazabal Galarza / Susana Cosme / José António Pereira / Israel Espi

1207 Cultivos de Época Romana no Baixo Sabor: continuidade em tempos de mudança? João Pedro Tereso / Sérgio Simões Pereira / Filipe Santos / Luís Seabra / Filipe Vaz

1221 A casa romana na Hispânia: aplicação dos modelos itálicos nas províncias ibéricas Fernanda Magalhães / Diego Machado / Manuela Martins

1235 As pinturas murais romanas da Rua General Sousa Machado, n. ${ }^{5}$ 1, Chaves José Carvalho

1243 Trás do Castelo (Vale de Mir, Pegarinhos, Alijó) - Uma exploração agrícola romana do Douro

Tony Silvino / Pedro Pereira

1255 A sequência de ocupação no quadrante sudeste de Bracara Augusta: as transformações de uma unidade doméstica Lara Fernandes / Manuela Martins

1263 Os Mosaicos com decoração geométrica e geométrico-vegetalista dos sítios arqueológicos da área do Conuentus Bracaraugustanus. Novas abordagens quanto à conservação, restauro, decoração e datação Maria de Fátima Abraços / Licínia Wrench

1277 “Casa Romana” do Castro de São Domingos (Cristelos, Lousada): Escavação, Estudo e Musealização Paulo André de P. Lemos

1291 A arqueobotânica no Castro de Guifões (Matosinhos, Noroeste de Portugal): O primeiro estudo carpológico

Luís Seabra / Andreia Arezes / Catarina Magalhães / José Varela / João Pedro Tereso 
1305 Um Horreum Augustano na Foz do Douro (Monte do Castelo de Gaia, Vila Nova de Gaia) Rui Ramos

1311 Ponderais romanos na Lusitânia: padrões, formas, materiais e contextos de utilização Diego Barrios Rodríguez

1323 Um almofariz centro-itálico na foz do Mondego

Marco Penajoia

1335 Estruturas romanas de Carnide - Lisboa Luísa Batalha / Mário Monteiro / Guilherme Cardoso

1347 O contexto funerário do sector da "necrópole NO" da Rua das Portas de S. Antão (Lisboa): o espaço, os artefactos, os indivíduos e a sua interconectividade na interpretação do passado Sílvia Loja, José Carlos Quaresma, Nelson Cabaço, Marina Lourenço, Sílvia Casimiro, Rodrigo Banha da Silva, Francisca Alves-Cardoso

${ }_{1361}$ Povoamento em época Romana na Amadora - resultados de um projeto pluridisciplinar Gisela Encarnação / Vanessa Dias

1371 A Arquitectura Residencial em Mirobriga (Santiago do Cacém): contributo a partir de um estudo de caso Filipe Sousa / Catarina Felício

${ }_{1385}$ O fim do ciclo. Saneamento e gestão de resíduos nos edifícios termais de Mirobriga (Santiago do Cacém)

Catarina Felício / Filipe Sousa

1399 Balsa, Topografia e Urbanismo de uma Cidade Portuária Vítor Silva Dias / João Pedro Bernardes / Celso Candeias / Cristina Tété Garcia

1413 No Largo das Mouras Velhas em Faro (2017): novas evidências da necrópole norte de Ossonoba e da sua ocupação medieval Ricardo Costeira da Silva / Paulo Botelho / Fernando Santos / Liliana Nunes

1429 Instrumentos de pesca recuperados numa fábrica de salga em Ossonoba (Faro) Inês Rasteiro / Ricardo Costeira da Silva / Paulo Botelho

1439 A Necrópole Romana do Eirô, Duas Igrejas (Penafiel): intervenção arqueológica de 2016 Laura Sousa / Teresa Soeiro

1457 Ritual, descarte ou afetividade? A presença de Canis lupus familiaris na Necrópole Noroeste de Olisipo (Lisboa)

Beatriz Calapez Santos / Sofia Simões Pereira / Rodrigo Banha da Silva / Sílvia Casimiro / Cleia Detry / Francisca Alves Cardoso

1467 Dinâmicas económicas em Bracara na Antiguidade Tardia Diego Machado / Manuela Martins / Fernanda Magalhães / Natália Botica

1479 Cerâmicas e Vidros da Antiguidade Tardia do Edifício sob a Igreja do Bom Jesus (Vila Nova de Gaia) Joaquim Filipe Ramos

1493 Novos contributos para a topografia histórica de Mértola no período romano e na Antiguidade Tardia Virgílio Lopes

\section{8. Época Medieval}

1511 Cerâmicas islâmicas no Garb setentrional "português": algumas evidências e incógnitas Constança dos Santos / Helena Catarino / Susana Gómez / Maria José Gonçalves / Isabel Inácio / Gonçalo Lopes / Jacinta Bugalhão / Sandra Cavaco / Jaquelina Covaneiro / Isabel Cristina Fernandes / Ana Sofia Gomes 
1525 Contributo para o conhecimento da cosmética islâmica, em Silves, durante a Idade Média Rosa Varela Gomes

1537 Yábura e o seu território - uma análise histórico-arqueológica de Évora entre os séculos VIII-XII José Rui Santos

1547 A encosta sul do Castelo de Palmela - resultados preliminares da escavação arqueológica Luís Filipe Pereira / Michelle Teixeira Santos

1559 A igreja de São Lourenço (Mouraria, Lisboa): um conjunto de silos e de cerâmica medieval islâmica

Andreia Filipa Moreira Rodrigues

1571 O registo material de movimentações populacionais no Médio Tejo, durante os séculos XII-XIII. Dois casos de "sunken featured buildings", nos concelhos de Cartaxo e Torres Novas Marco Liberato / Helena Santos / Nuno Santos

1585 O nordeste transmontano nos alvores da Idade média. Notas para reflexão Ana Maria da Costa Oliveira

1601 Sepulturas escavadas na rocha do Norte de Portugal e do Vale do Douro: primeiros resultados do Projecto SER-NPVD

Mário Jorge Barroca / César Guedes / Andreia Arezes / Ana Maria Oliveira

1619 "Portucalem Castrum Novum" entre o Mediterrâneo e o Atlântico: o estudo dos materiais cerâmicos alto-medievais do arqueossítio da rua de D. Hugo, nํ. 5 (Porto) João Luís Veloso

1627 A Alta Idade Média na fronteira de Lafões: notas preliminares sobre a Arqueologia no Concelho de Vouzela

Manuel Luís Real / Catarina Tente

1641 Um conjunto cerâmico medieval fora de portas: um breve testemunho aveirense Susana Temudo

${ }_{1651}$ Os Lóios do Porto: uma perspetiva integrada no panorama funerário da Baixa Idade Média à Época Moderna em meios urbanos em Portugal

Ana Lema Seabra

1659 O Caminho Português Interior de Santiago como eixo viário na Idade Média Pedro Azevedo

1665 Morfologia Urbana: Um exercício em torno do Castelo de Ourém André Donas-Botto / Jaqueline Pereira

1677 Intervenção arqueológica na Rua Marquês de Pombal/Largo do Espírito Santo (Bucelas, Loures)

Florbela Estêvão / Nathalie Antunes-Ferreira / Dário Ramos Neves / Inês Lisboa

1691 O Cemitério Medieval do Poço do Borratém e a espacialidade funerária na cidade de Lisboa Inês Belém / Vanessa Filipe / Vasco Noronha Vieira / Sónia Ferro / Rodrigo Banha da Silva

1705 Um Espaço Funerário Conventual do séc. XV em Lisboa: o caso do Convento de São Domingos da Cidade Sérgio Pedroso / Sílvia Casimiro / Rodrigo Banha da Silva / Francisca Alves Cardoso

\section{9. Época Moderna e Contemporânea}

1721 Arqueologia Moderna em Portugal: algumas reflexões críticas em torno da quantificação de conjuntos cerâmicos e suas inferências históricas e antropológicas Rodrigo Banha da Silva / André Bargão / Sara da Cruz Ferreira

1733 Faianças de dois contextos entre os finais do século XVI e XVIII do Palácio dos Condes de Penafiel, Lisboa

Martim Lopes / Tomás Mesquita 
1747 Um perfil de consumo do século XVIII na foz do Tejo: O caso do Mercado da Ribeira, Lisboa Sara da Cruz Ferreira / Rodrigo Banha da Silva / André Bargão

1761 Os Cachimbos dos Séculos XVII e XVIII do Palácio Mesquitela e Convento dos Inglesinhos (Lisboa)

Inês Simão / Marina Pinto / João Pimenta / Sara da Cruz Ferreira / André Bargão / Rodrigo Banha da Silva

1775 "Tomar os fumos da erua que chamão em Portugal erua sancta». Estudo de Cachimbos provenientes da Rua do Terreiro do Trigo, Lisboa

Miguel Martins de Sousa / José Pedro Henriques / Vanessa Galiza Filipe

1787 Cachimbos de Barro Caulínitico da Sé da Cidade Velha (República de Cabo Verde)

Rodrigo Banha da Silva / João Pimenta / Clementino Amaro

1801 Algumas considerações sobre espólio não cerâmico recuperado no Largo de Jesus (Lisboa) Carlos Boavida

1815 Adereços de vidro, dos séculos XVI-XVIII, procedentes do antigo Convento de Santana de Lisboa (anéis, braceletes e contas)

Joana Gonçalves / Rosa Varela Gomes / Mário Varela Gomes

1837 Da ostentação, luxo e poder à simplicidade do uso quotidiano: arqueologia e simbologia de joias e adornos da Idade Moderna Portuguesa Jéssica Iglésias

1849 Os amuletos em Portugal - dos objetos às superstições: o coral vermelho Alexandra Vieira

1865 Cerâmicas de Vila Franca de Xira nos séculos XV e XVI Eva Pires

1879 «Não passa por teu o que me pertence». Marcas de individualização associadas a faianças do Convento de Nossa Senhora de Aracoeli, Alcácer do Sal Catarina Parreira / Íris Fragoso / Miguel Martins de Sousa

1891 Cerâmica de Leiria: alguns focos de produção

Jaqueline Pereira / André Donas-Botto

1901 Os Fornos na Rua da Biquinha, em Óbidos Hugo Silva / Filipe Oliveira

1909 A casa de Pêro Fernandes, contador dos contos de D. Manuel I: o sítio arqueológico da Silha do Alferes, Seixal (século XVI) Mariana Nunes Ferreira

1921 O Alto da Vigia (Sintra) e a vigilância e defesa da costa Alexandre Gonçalves / Sandra Santos

1937 O contexto da torre sineira da Igreja de Santa Maria de Loures Paulo Calaveira / Martim Lopes

1949 A Necrópole do Hospital Militar do Castelo de São Jorge e as práticas funerárias na Lisboa de Época Moderna Susana Henriques / Liliana Matias de Carvalho / Ana Amarante / Sofia N. Wasterlain

1963 SAND - Sarilhos Grandes Entre dois Mundos: o adro da Igreja e a Paleobiologia dos ossos humanos recuperados

Paula Alves Pereira / Roger Lee Jesus / Bruno M. Magalhães

1975 Expansão urbana da vila de Cascais no século XVII e XVIII: a intervenção arqueológica na Rua da Vitória no 15 a 17

Tiago Pereira / Vanessa Filipe

1987 Novos dados para o conhecimento do Urbanismo de Faro em época Moderna Ana Rosa 
1995 Um exemplo de Arqueologia Urbana em Alcoutim: o Antigo Edifício dos CTT Marco Fernandes / Marta Dias / Alexandra Gradim / Virgílio Lopes / Susana Gómez Martínez

2007 Palácio dos Ferrazes (Rua das Flores/Rua da Vitória, Porto): a cocheira de Domingos Oliveira Maia

Francisco Raimundo

2021 As muitas vidas de um edifício urbano: História, Arqueologia e Antropologia no antigo Recreatório Paroquial de Penafiel Helena Bernardo / Jorge Sampaio / Marta Borges

2035 O convento de Nossa Senhora da Esperança de Ponta Delgada: o contributo da arqueologia para o conhecimento de um monumento identitário João Gonçalves Araújo / N’Zinga Oliveira

2047 Arqueologia na ilha do Corvo... em busca da capela de Nossa Senhora do Rosário Tânia Manuel Casimiro / José Luís Neto / Luís Borges / Pedro Parreira

2059 Perdidos à vista da Costa. Trabalhos arqueológicos subaquáticos na Barra do Tejo Jorge Freire / José Bettencourt / Augusto Salgado

2071 Arqueologia marítima em Cabo Verde: enquadramento e primeiros resultados do projecto CONCHA

José Bettencourt / Adilson Dias / Carlos Lima / Christelle Chouzenoux / Cristóvão Fonseca / Dúnia Pereira / Gonçalo Lopes / Inês Coelho / Jaylson Monteiro / José Lima / Maria Eugénia Alves / Patrícia Carvalho / Tiago Silva

2085 Trabalhos arqueológicos na Cidade Velha (Ribeira Grande de Santiago, Cabo Verde): reflexões sobre um projecto de investigação e divulgação patrimonial André Teixeira / Jaylson Monteiro / Mariana Mateus / Nireide Tavares / Cristovão Fonseca / Gonçalo C. Lopes / Joana Bento Torres / Dúnia Pereira / André Bargão / Aurélie Mayer / Bruno Zélie / Carlos Lima / Christelle Chouzenoux / Inês Henriques / Inês Pinto Coelho / José Lima / Patrícia Carvalho / Tiago Silva

2103 A antiga fortificação de Quelba / Khor Kalba (E.A.U.). Resultados de quatro campanhas de escavações, problemáticas e perspectivas futuras Rui Carita / Rosa Varela Gomes / Mário Varela Gomes / Kamyar Kamyad

2123 Colónias para homens novos: arqueologia da colonização agrária fascista no noroeste ibérico Xurxo Ayán Vila / José Mạ . Señorán Martín 


\title{
ARQUEOLOGIA E MODERNIDADE: UMA REVISITAÇÃO PESSOAL E BREVE DE ALGUNS ASPETOS DA OBRA HOMÓNIMA DE JULIAN THOMAS DE 2004
}

\author{
Vítor Oliveira Jorge ${ }^{\mathrm{I}}$
}

\begin{abstract}
“O problema (...) é que o pensamento moderno depende tão fortemente de fundamentos e origens, e contudo, em última análise, as origens dos povos e organizações contemporâneos parecem ser inacessíveis. Essa é uma das razões pelas quais a arqueologia tem sido tão importante para a modernidade e, no entanto, sempre falha em alcançar o que se espera dela: trazer o passado à sua presença total.”
\end{abstract}

(Thomas, 2004, p. 233)

“(...) o objeto que a arqueologia estuda - o passado - está ausente, e a disciplina busca continuamente um certo grau de certeza que é difícil de atingir."

(idem, ibidem, p. 247)

RESUMO

Em 2004, Julian Thomas (Universidade de Manchester), publicou uma obra importante: "Archaeology and Modernity", na qual procurou mostrar que a arqueologia é uma ciência, uma disciplina e uma atividade que só poderiam ter surgido na nossa Modernidade, isto é, no período que se abriu com o século XVII europeu. Passados 16 anos, pode fazer-se um balanço e certamente propor alguns tópicos novos, ainda não abordados naquele livro, quer por opção do autor, quer pelo próprio desenvolvimento dos nossos conhecimentos. Esta comunicação pretende ser um pequeno contributo nesse sentido, muito embora assumindo um carácter pessoal e muito parcelar. Se em 2004 as conclusões e propostas finais do livro deviam ser discutidas, o tempo entretanto decorrido mudou obviamente o quadro das questões.

Palavras-chave: Modernidade, Arqueologia, Filosofia, Pensamento crítico.

\section{ABSTRACT}

In 2004, Julian Thomas (University of Manchester), published an important work: "Archaeology and Modernity" in which he sought to show that archeology is a science, a discipline and an activity that could only have appeared in our Modernity, that is, in the period that opened with the European seventeenth century. After 16 years, we can take stock of it and certainly propose some new topics, not yet covered in that book, either at the option of the author, or because of the development of our knowledge. This paper intends to be a short contribution in that sense, although assuming its personal and very partial nature. If in 2004 the book's final conclusions and proposals should be discussed, the time that has elapsed since then has obviously changed the picture of the issues.

Keywords: Modernity, Archaeology, Philosophy, Critical thought. 
Acentuando que só com a Modernidade (fenómeno e período da história ocidental que tendeu a alastrar a todo o mundo, adquirindo facetas muito diversificadas; houve, claro, muitas formas de "modernização") a arqueologia teria sido possível, o autor do livro que me serve de base de raciocínio refere como essa Modernidade é toda ela feita de contradições e paradoxos.

Algumas ideias centrais que caracterizam esse período da história ocidental - a admitir que pode ser considerado assim - são expostas logo nas páginas 2 e 3 (sem preocupação de hierarquizar os tópicos): capitalismo (num momento de grande desenvolvimento, e certamente a característica que envolve todas as outras...); aparecimento dos estados-nação; industrialização; desenvolvimento de comunicações e transportes; mercantilismo; controlo da violência pelo Estado; vigilância, fiscalização; luta política permanente; ampliação do modo de vida urbano; agitação, turbulência, mudança contínuas; declínio da tradição, nomeadamente das crenças religiosas; insatisfação, inquietação; permanente crítica da própria modernidade por si mesma; crises frequentes sem aparente resolução; fragmentação social, individualismo; legislação estatal para assegurar códigos laicos de conduta moral e manter a ordem; vontade de planeamento e de previsão do futuro; tendência para as "grandes narrativas" com a sua componente utópica, etc.

De facto, uma valorização do imanente em relação ao transcendente, de uma realidade material e "presente" em oposição à autoridade espiritual do "passado", por um lado, e uma acentuação do "novo" (palavra quase mágica) relativamente ao antigo, tradicional, caduco, são, por assim dizer, tópicos quase obsessivos da Modernidade. A quem ingenuamente surpreendesse que a arqueologia (à letra, ciência das coisas antigas) pudesse precisamente ocorrer nesta altura (e só nela), Thomas volta a lembrar por exemplo, na página 53 , que “(...) a arqueologia é também caracteristicamente moderna porque afirma que se pode criar conhecimento novo a partir de coisas materiais." E, na página seguinte, acrescenta: “(...) a arqueologia usa coisas materiais para abordar aspectos do passado que não são referidos em nenhum texto escrito." Por vezes, em todo o livro, aparece também a expressão "cul- tura material”2 ou, mesmo, o conceito mais genérico de "materialidade(s)".

"Coisas materiais" são portanto, neste contexto, realidades que contrastam com documentos escritos, e que pertencem ao que o autor também designa "mundo material" (cf., por ex., p. 13). Esse mundo de conhecimentos potenciais, por oposição nomeadamente ao dos livros, tinha sido trazido à tona tipicamente pelo empirismo de um Bacon, representante, entre muitos outros, da "nova ciência" que a Modernidade fez emergir, sobretudo a partir do século XVII. Como é sabido, o racionalismo ocidental, no seu sentido genérico, pode ser tipificado, nas suas duas facetas, pelo mesmo Bacon, do lado da observação e valorização da realidade direta, e, do ângulo mais propriamente abstrato, por Descartes, consagrando sobretudo um pensamento de cariz matemático. Muito influenciado por Martin Heidegger ${ }^{3}$, Thomas irá ao longo do livro sempre criticar a dicotomia cartesiana mente-corpo, o que é coerente para quem não valorize a linha que, por Platão e Descartes, culmina em Hegel ("a substância é sujeito"), e que considera Descartes como o criador do sujeito moderno, sem o qual teria sido impossível Kant e de um modo geral todo o chamado "idealismo alemão" e, claro, mais perto de nós,

\footnotetext{
2. Conceito que, mais recentemente, o autor reviu, considerando-o "uma contradição nos termos", com o que estou inteiramente de acordo (conversa pessoal).

3. Heidegger foi um dos maiores pensadores do século XX, apesar de ter aderido à ideologia nazi, como se tem vindo a comprovar cada vez mais. Mas isso nem por sombras elimina a sua importância filosófica. J. Thomas, na sua obra de 2004, justifica a esta luz (filosófica) a sua opção (fascínio pela obra heideggeriana), o que aliás se não tornaria necessário. Por exemplo, Žižek (que fez a sua tese sobre Heidegger em Liubliana), aborda o pensamento filosófico do autor alemão muitas vezes, nomeadamente em O Sujeito Incómodo (The Ticklish Subject, 1999). Na introdução ao seu tratado sobre Hegel, Menos Que Nada. Hegel e a Sombra do Materialismo Dialético (tenho várias edições, cito a francesa, p. 18) Žižek cartografa sinteticamente o campo filosófico-ideológico atual em 4 posições, designando a $4^{\underline{a}}$ como "pensamento da finitude transcendental (que culmina com Heidegger)." E Žižek acrescenta (ib.): A tese deste livro ["Menos Que Nada..."] é dupla: (1) há uma posição que escapa a estas quatro posições, a saber a de um desfasamento ou de uma ruptura pré-transcendental, a que Freud chama a pulsão; (2) esta dimensão constitui o próprio núcleo da subjetividade moderna."
} 
a obra crucial de um "anti-filósofo", o psicanalista Jacques Lacan. ${ }^{4}$

A realidade material é pois um dos conceitos a debater aqui, bem como um outro que, percorrendo todo o livro, aparece logo na primeira frase que abre o mesmo: "A arqueologia investiga o passado por meio de coisas materiais.” (p. 1); refiro-me, claro, à noção de passado, naturalmente por oposição à de presente. É importante este aspecto, porque logo na mesma abertura da obra, Thomas concebe passado e presente em articulação relacional, referindo que não se trata apenas, em arqueologia, de reconstruir "como as coisas foram", mas de “(...) estabelecer uma relação entre o passado e o presente.” (ib.). Essa relação (noção inspirada em Gadamer) impõe-nos uma compreensão de como ambos, passado e presente, estão em diálogo, através de uma distância produtiva que nos permite continuamente "(...) apreender mais, tanto acerca dos mundos passados como de nós próprios." (ib.). Assim, pois, tentar dar um significado ao "passado" é o mesmo movimento de tentar compreender o nosso "presente": uma atitude dialógica e não uma posição positivista, dominada pelo desejo de reconstituir, ou reconstruir, essa entidade inefável por excelência que seria "o passado".

Por que razão este livro foi importante quando apareceu, nos princípios deste século, e ainda hoje nos convida à releitura e reflexão? Porque nesta síntese um arqueólogo, especialista do que em Portugal chamaríamos a Pré-história recente, claramente mostra como é fundamental, para cada um de nós, subir um degrau (no sentido da abstração, da teoria, do pensamento transdisciplinar) e tentar compreender, desde aí, por que é que a arqueologia passou a existir e quais as suas ligações multidireccionais com todo esse mundo que designamos Modernidade. Ou seja, tentar ver de um modo mais global por que motivo nos dedicamos a esta atividade, que condições a tornaram possível e mesmo atraente, para nós, para o público, para as instituições que a ensinam e promovem.

4. Numa época confusa como aquela em que vivemos, no dealbar da terceira década do século XXI, estou convencido que esta via é a mais produtiva para um pensamento progressista e lúcido, afastado das tendências pós-modernas e relativistas, e em particular de um fantasma que assola alguma arqueologia atual, a dos chamados "novos materialismos", mesmo na sua dimensão mais consistente, a da "ontologia orientada para os objetos."
Esta atitude teórico-filosófico-histórica não era nova em 2004 na trajetória de Thomas: perpassa toda a sua obra, e nomeadamente já antes, em 1996, ele nos tinha oferecido um livro tipicamente "heideggeriano", "Time, Culture and Identity”, que subtitulou: "an interpretive archaeology" (uma arqueologia interpretativa, "corrente" que se insere nas arqueologias pós-processuais), e no qual abordava claramente alguns dos temas que aqui desenvolve. Como todo o investigador de qualidade, arguto e atento ao seu presente, Julian Thomas sempre tem mesclado produtivamente teoria e prática arqueológica, num balancear constante; assim a visão que nos dá do Neolítico das chamadas Ilhas Britânicas é extremamente rica e susceptível de inspirar, mesmo, a arqueologia continental. Esta atitude não é tão frequente quanto seria para desejar.

Mas voltemos ao livro, não para esgotar a sua rica extensão de questões (comentá-las daria outro livro...), mas para apenas aflorar alguns tópicos. O próprio autor, no prefácio (p. xi) apresenta-o como dividido em três partes: uma primeira, abarcando os dois capítulos iniciais, e correspondendo a uma exposição geral da interligação da arqueologia com a Modernidade; uma segunda, em que em sucessivos capítulos são abordadas questões de epistemologia, depois de processos históricos e naturais, da importância do estado-nação em toda esta problemática, do humanismo e da sua atenção à esfera individual, das relações entre profundidade e superfície, da mente, cognição, perceção e conhecimento, e finalmente do problema da matéria e materialidade. O livro remata com uma conclusão em que são apresentadas sugestôes no sentido de uma "arqueologia contra-moderna”, ou seja, procurando contribuir para a superação do estado da arqueologia na Modernidade. Embora estando de acordo com grande parte do que aí se afirma, julgo que esse capítulo final seria decerto aquele que o próprio autor hoje gostaria eventualmente de reescrever, havendo ali "pano para mangas", quer no sentido de um profícuo debate em torno do que lá está, quer em torno do que lá (do meu ponto de vista, é claro) não está.

Interrogação primordial: que é “o passado", que significa "trazer o passado ao presente", que significa o "lamento" (tão frequente entre nós, arqueólogos, que por vezes parecemos ser os autores de um "saber infeliz consigo mesmo") de que o passado, supostamente o "objeto" da arqueologia, "se ausentou" ? 
O passado é uma representação, uma representação de uma das modalidades do tempo linear humano (não falo do tempo da física, assunto em que não sou competente), que evidentemente não é possível concretizar, e muito menos totalizar. Por isso, trata-se de um produto da nossa imaginação, de uma certa forma, mesmo, do nosso "delírio", se quisermos. Tal como as outras duas figuras fantasmáticas daquele tempo humano linear, o presente e o futuro. Como tal, não pode ser objecto de qualquer "ciência", de qualquer conhecimento que deseje reger-se por normas compartidas por uma comunidade de estudiosos, para atingir um objetivo por todos reconhecido como o mais certo, ou provável, em cada momento.

Que significaria, por exemplo, "presentificar" um qualquer "presente” que já decorreu? Quais as suas balizas? A que escala se daria essa presentificação? No caso concreto da arqueologia, seria podermos emergir, como numa espécie de filme, sonho ou pesadelo, numa realidade qualquer anterior à nossa, quais etnólogos de outro tempo, inserirmo-nos nessa realidade e nela sobreviver, para podermos dar conta das estruturas sociais e económicas, das representações, dos ditos e interditos desse espaço-tempo?... Mas quais os seus limites, qual a forma de diálogo que poderíamos estabelecer com essa realidade fantasmática que se ausentou? É óbvio que o que digo é do domínio do impossível, ou da realidade virtual, ou de uma manifestação de alteração da minha consciência no sentido do total descolamento da realidade (para não dizer da demência). Não, o objeto da arqueologia não pode ser o passado, nem podemos estabelecer genericamente $o$ nosso método como uma dialogia entre duas representações ilusórias, o presente e o passado. Pois obviamente não há nada de mais diáfano e indefinível do que o presente.

Tudo o que de facto temos, individual e colectivamente, e sobre que se debruça a arqueologia, são ruínas ou vestígios, a descoberto, meio enterrados ou submersos, ou completamente invisíveis. Com isso nos confrontamos, sobre isso nos debruçamos, segundo regras e leis, com uma metodologia já firmada, procurando recolher o máximo de informação possível sobre algo, estendido num espaço, o qual perdeu sentido para a vida moderna, não tem hoje função. Ora o poder moderno não deixa nada de fora, é global, e nenhuma caracterização desse poder pode jamais esquecer que ele é exercido, sobre- tudo a partir dos anos 70 do século XX, no quadro de um capitalismo neoliberal e de uma sociedade de consumo hedonista que é hoje, para falar depressa, o novo "ópio do povo". Todos estamos nela, todos fomos absorvidos por ela.

A essa massa imensa, dispersa, desigual, tantas vezes abandonada, das ruínas ou vestígios de vidas anteriores, não chamaria de modo algum "registo arqueológico" (tradução do inglês "archaeological record"), porque um registo se conota em geral com uma autoria e com uma intencionalidade definida ou definível, mas antes e apenas realidade arqueológica. A realidade arqueológica está aí, e é o nosso foco de trabalho por excelência. Essa intervenção "reanima" um local em princípio abandonado, pois é uma tarefa de equipa, no qual se confrontam discursos e propostas, metodologias, etc. Claro que a sua caracterização como sítio arqueológico digno de intervenção implica todo um trabalho prévio, pleno de condicionalismos de toda a espécie, e um trabalho ulterior, nomeadamente de gabinete, laboratório, museu, também sujeito a muitas condicionantes, como bem sabemos.

Que procuramos com toda essa atividade? Parto aqui da experiência paradigmática de um caso particular de arqueologia terrestre em ambiente rural, porque a arqueologia em geral defronta-se com uma amplitude muito grande, diversificada, de situações. E assumo-a como uma investigação (o que já vai sendo raro...), a única que merece o nome de ciência. Procuramos transformar as características de um local, sobre o qual vamos exercendo uma ação de decapagem ("escavação"), num conjunto de modelos, trabalháveis fora desse local, a duas ou mais dimensões. Como todos os sítios arqueológicos são contentores de unidades mais pequenas de informação, estas são registadas e, sempre que possível, sob a forma de amostras, transportadas para local de estudo. Estes artefactos (ou ecofactos) mais pequenos, exumados do artefacto maior que é o próprio local, são desse modo descontextualizados. Ficamos assim progressivamente com um sítio mais ou menos transformado pela nossa ação, e com um arquivo de dados potencialmente imenso. Só ambos, articulados, fazem sentido. O local é mudo e os registos são sempre esqueléticos, pobres, em relação a uma experiência subjetiva, irrepetível, que é a de uma escavação em curso. Todos temos a experiência da desilusão de voltar a um local que escavámos e depois foi restaurado e "musealizado": quase todos os problemas 
encontrados foram elididos no produto final visível, visitável, onde às vezes, para nosso espanto, encontramos "guias" a explicar coisas às pessoas, fascinadas com as estórias, coisas essas que nada, ou pouco, têm a ver com o que se passou connosco ali. Sim, há uma cumplicidade afetiva e intelectual dos arqueólogos com os sítios que abordaram, que corresponderam a uma parte mais ou menos longa das suas vidas, e que por vezes já não reconhecem, passada a tecnologia dos restauradores e "museógrafos", em geral empresas que saltam de tarefa para tarefa. Para o arqueólogo um sítio arqueológico não é um local de tarefas: é um nó de vivências, intransmissível.

Que temporalidades encontramos na realidade arqueológica enquanto temos a felicidade de a estudar? Temporalidades locais, parciais, indícios de um antes e um depois, que na maior parte dos casos são difíceis de conectar entre si. Mais do que evidências, realidades facilmente explicáveis, deparamo-nos com aporias, com irresolúveis, isto é, com realidades físicas, materiais, que não são passíveis de interpretação numa dada fase da história dos trabalhos no local. Essas áreas, ou micro-áreas, devem ser assim acauteladas, protegidas, com paragem da intervenção, para um depois. Como um livro de que não percebêssemos uma passagem, mas nem por isso deixamos de continuar a ler, esperando um efeito de compreensão retroativa e contextual, mais à frente. As realidades arqueológicas, e em particular as muitas que a uma primeira abordagem nos aparecem como incompreensíveis, podem resultar da ação humana, eventualmente de dinâmicas naturais, mas, na maior parte dos casos, resultam de um imbricação - como toda a realidade arqueológica - entre o humano (intencional ou não) e o natural. Seria muito importante que, em vez de nos seus relatórios os arqueólogos reportarem apenas o que foi entendido, como se todas as peças de um eventual puzzle entroncassem umas nas outras, aplicando uma temporalidade linear à própria lógica hesitante e dialéctica do seu trabalho de campo, expusessem documentalmente as tais aporias, dúvidas, impasses, porque elas seriam cruciais para outros (ou eles próprios) mais tarde poderem prosseguir a pesquisa. Para esta ter de facto um cariz científico, quer dizer, ser tanto quanto possível recuperável por outrem. Muito antes de servir para contar estórias, ou a história do sítio, da região, e para reconstituir seja o que for, etc., a atividade descrita reporta-se à incidência da atenção sobre um local, incidência que idealmen- te não teria condicionalismos apertados de tempo (como qualquer outra pesquisa científica) nem de conclusões precipitadas por imposição exterior, alheia à dinâmica interna da pesquisa.

Onde está o "passado" em tudo isto?... mais uma vez, não tem sentido imediato tal fantasma, embora a experiência repetida de um local, por uma equipa, durante anos, essa sim, crie uma história, uma tradição mesmo, uma afinidade e uma afetividade (positiva ou negativa) entre as pessoas envolvidas, como já referi. A arqueologia é isto: um trabalho de equipa visando em última análise dar sentido(s) a um local desafetado pela Modernidade. ${ }^{5}$ Se algum passado existe, é esse: a história da pesquisa e as etapas por que foi passando e as questões e hipóteses que foi desenvolvendo, e que tentam explicar a biografia do local, podendo apontar, evidentemente, para um âmbito mais alargado em termos de problemática. Porque é importante confrontar o público não com explicações domésticas, todas prontas, sobre um suposto "passado", mas com problemas, perguntas, questões, sobre o diálogo que se foi estabelecendo ali entre suspeitas e certezas, entre hipóteses e confirmações, e... entre perguntas que não chegaram a ter resposta. É extremamente importante, crucial mesmo, saber conviver com a dúvida, a incerteza, a perda, em suma, com o caracter não-Todo da realidade, e portanto também com a contingência do nosso pensamento, que é parte dessa realidade.

Vejamos agora: coisas materiais, mundo material, cultura material, materialidade(s), que é isso?... Em última análise, o conceito de matéria e de materialismo reporta-nos para uma velha dualidade, a da substância (conceito que Thomas usa nalguns momentos do livro) e do sujeito. Ambos os conceitos são muito complexos nas suas diversas aceções, que atravessam toda a história da filosofia. Substância seria aquilo que persiste, que subjaz ao

\footnotetext{
5. Como esta tem horror ao vazio, e visa o ordenamento do território, a arqueologia insere-se aí, nesses "buracos" do "desenvolvimentismo", em locais de paragem, onde depois ou ao mesmo tempo dos arqueólogos vêm (pelo menos idealmente) os restauradores e toda uma bateria de curiosos e jornalistas, fazer a mediação do local para os visitantes. Entretanto, os arqueólogos e outros cientistas com quem trabalham terão produzido uma vasta quantidade de publicações, e deverão, por uma questão ética, apresentar as suas conclusões numa brochura ou qualquer outro suporte que torne inteligível para outros o que ali se passou desde que se iniciaram os trabalhos.
} 
que muda, ao que aparece; sujeito, reportar-se-ia à entidade pensante, ao ser humano precário que, perante a substância, procura dar dela uma explicação, compreendê-la. O filósofo esloveno Mladen Dolar, numa explicação notável pela sua clareza ${ }^{6}$, diz-nos que muitas realidades foram candidatas à ideia de substância; uma delas foi o materialismo. "Matéria”, pois, valorizada como o que é essencial, por oposição a ideia ou espírito; materialismo contra idealismo. Claro que isto é uma simplificação enorme. Dolar é um hegeliano nosso contemporâneo, como muitos outros, aliás, uma vez que Hegel foi o grande denegado da filosofia ocidental, começando porém, nos últimos tempos, o que é animador, a ter uma importância cada vez maior. Para Hegel, matéria era uma abstração pura, ao mesmo título de espírito: produtos do pensamento, realidades que nunca ninguém viu. Nesse sentido, valorizar a matéria como conceito-chave do nosso pensamento é uma simplificação irrisória. E Hegel, que não apreciava aforismos, tem também aquela célebre frase que já atrás invoquei, "a substância é sujeito", o que vem na mesma linha, mas praticamente é o conceito-chave de toda a arquitetura fabulosa da sua filosofia dialética. $\mathrm{Na}$ verdade, quando penso em algo exterior a mim, quer o verbalize ou não, eu, como sujeito, estou já a entrar num "movimento" de mediação; ou seja, se considero que algo é substância, elemento supostamente último e universal, estou já a sair do modo da substancialidade, da lógica da conectividade. A substância é sujeito na medida em que é mediatizada pelo sujeito, e portanto mesmo a ideia de materialismo é imaterial. A matéria é uma ideia, um produto do pensamento. E daí que possamos também afirmar que o absoluto é sujeito, porque absoluto não é algo de transcendente e inacessível, de numenal, como na filosofia de Kant (que tem sido a base de quase todo o pensamento ocidental, o qual lamentavelmente retrogradou em relação a Hegel $^{7}$, mas representa uma realidade histórica, um conhecimento em que efetivamente é superada, no

6. Ver o vídeo, com bloco notas à mão: https://youtu.be/ UBlOABhRglo (acedido em julho 2020).

7. O próprio Marx, o incontornável Marx, não entendeu totalmente Hegel, do qual partiu, deixando-nos uma obra notável sobre o capitalismo, a alienação, a ideologia, mas abrindo caminho a uma visão teleológica da história (o proletariado como portador providencial do futuro redentor da exploração) que, como se verificou, não acertou. momento concreto (e apenas só nesse, porque nem a história nem o espírito jamais param) em que se efetiva, a dicotomia entre pensamento e realidade. Voltando agora à minha circunstância concreta de arqueólogo: quando me debruço, com outro(a)s, sobre um sítio arqueológico, não me interessa nada estar a gastar tempo com especulações sobre a sua "materialidade" ou não. O que se nos coloca evidentemente são questões práticas e metodológicas (que obviamente são também teóricas) de como melhor abordar em conjunto uma realidade que, como em toda a ciência, é opaca, consistindo o nosso trabalho em procurar desfazer essa opacidade numa multidão de outras opacidades menores (os "dados", os registos), esperando torná-los compreensíveis (ou pelo menos não tão opacos) através dos métodos aplicados, métodos esses validados pelas normas em vigor em arqueologia, que podemos e devemos sempre ampliar/corrigir criticamente e aplicar a cada caso com precisão e disciplina de grupo, dentro de um diálogo democrático. Estou de acordo nesse aspeto com Julian Thomas quando defende um trabalho colegial (p. 247 da obra em referência) $)^{8}$ na direção das escavações. Foi aliás o que sempre praticámos, desde 1998, no sítio pré-histórico de Castanheiro do Vento, concelho de Vila Nova de Foz Côa. A exigência científica dessa colegialidade, repartindo responsabilidades e motivando pessoas em diálogo e confrontação, é evidentemente muito maior (e muito mais justa) do que a de uma direção unipessoal, em que em última análise é um diretor clarividente que decide do caminho a seguir.

Se sou arqueólogo, se identifico com outro(a)s um sítio como fazendo parte da realidade arqueológica, se estamos autorizados pela autoridade pública a aí intervir, estamos a fazê-lo em nome de toda a comunidade científica e não só: a ética é aqui absolutamente essencial. Estamos a servir de mediadores entre uma realidade única, que vamos inexoravelmente alterar, e todos os outro(a)s, não apenas em nome de uma racionalidade abstrata, mas de algo de

8. Cito Thomas, p. 247: “Talvez em algumas circunstâncias a posição de diretor do sítio seja realmente supérflua e até limite a riqueza do que pode ser dito sobre o sítio. Pode não ser totalmente irreal imaginar um projeto de campo executado como coletivo, ou no qual pessoas diferentes se revezem na direção de diferentes fases da investigação." E acrescento: claro que isto pressupõe uma arqueologia de alto nível de qualidade em todos os aspetos, incluindo uma ética da lealdade e do rigor compartilhado. 
muito concreto, irrepetível, em termos de memória de interesse universal (construída hoje, agora, bem entendido). Quando um geólogo recolhe as suas observações e amostras neste e naquele local, claro que ele trabalha adentro de uma ciência diferente, com as suas complexidades, subtilezas, e regras próprias, exigindo muita experiência, esforço e saber; mas ele atua - pelo menos muitas vezes - sobre realidades repetíveis, no todo ou em parte. Nós, como arqueólogos, operamos sempre sobre entidades singulares, e todo o nosso esforço consiste em tentar passar da sua universalidade abstrata (estéril) para a sua universalidade concreta (viva, rica, porque iluminando facetas da realidade que podem ser novas e mesmo, até, únicas). O arqueólogo é o cientista do espaço que mais tempo demora numa determinada parcela do território, a qual tem a obrigação de compreender em si, e na sua conectividade com outros sítios vizinhos e toda a paisagem em geral. Porque jamais os seres humanos se circunscreveram aos meros espaços que a Modernidade nos deixou para atuar como arqueólogos.

Quem, por exemplo, entrou alguma vez na gruta de Lascaux (na original) percebe intuitivamente do que estou a falar, quando refiro que a arqueologia é uma experiência simultaneamente racional e emocional (retroalimentando-se uma à outra): sei que é um caso extremo, porque essa experiência nos marca para toda a vida, mas serve para exprimir a experiência arqueológica no seu limite e no seu fascínio. Quando saímos da gruta de Lascaux, onde só podemos permanecer uns 20 minutos e entrar com um técnico ${ }^{9}$ não nos perguntamos se acabamos de passar por uma realidade material ou espiritual. Percebemos sim, intuitivamente, que o que acabamos de ver nos prova, de forma impressiva, que os autores daquelas obras (melhor dizendo, de todo aquele espaço interior) eram já, no Paleolítico superior, pessoas como nós, extremamente complexas. Eis um exemplo de como a substância (uma realidade que desejaríamos que permanecesse para sempre, intacta, incólume ao tempo) é também sujeito. Ao olhá-la, com os olhos do ocidental do século XX, ao mergulhar no interior daquela cavidade, eu entro num mundo que era opaco na sua excecionalidade para um homem medieval, mesmo que ele tivesse por casualidade ali penetrado.

9. Pelo menos era assim em finais de 1996, quando fui autorizado a visitá-la.
Ou seja, há uma progressão do espírito humano, uma historicidade radical do mesmo: o que é para mim uma absoluta obra de arte, cujo sentido original (se é que o houve, em termos de "mistério" desvendado e explicado pelos seus autores - temos de nos lembrar da célebre elocução de Hegel de que os mistérios dos antigos egípcios eram também mistérios para eles mesmos) me escapa e acaba até por ser o menos importante, o que é que ele - esse sentido ou sentidos - seria para outras pessoas, de outros tempos/culturas: decerto algo de muito diferente do que me pode parecer, e algo que pode ter servido de base a narrativas muito diversas até ser selado no tempo até à sua descoberta casual.

É pois um absurdo estarmos a preocupar-nos com o facto de uma "coisa" ser material ou não. Há milhões de crucifixos, pois que a cena da crucificação é por assim dizer a mais importante, emblemática, tremendamente simbólica, da nossa cultura ocidental cristã. ${ }^{10}$ Mas um crucifixo, mesmo que todo partido e reduzido a pedaços, é uma entidade material, espiritual, ambas ao mesmo tempo, ou o que queiramos chamar-lhe, sejamos crentes ou não?... um crucifixo, ou fragmento do mesmo, toca-nos, afeta-nos, porque é um elemento da nossa cultura. Ora é com a mesma disposição de espírito que temos de abordar um sítio arqueológico: ali, em algum ou alguns momentos do tempo, estiveram pessoas, seres humanos, os quais, em tudo o que fizeram, não procediam como um animal ou uma árvore, mas antes tinham autoconsciência e portanto um inconsciente (mesmo que, com toda a probabilidade, não estivessem conscientes disso - nós, europeus, levámos milénios até aparecer Freud!! E ainda há muita gente culta que não percebeu a sua importância...). Tinham intencionalidade, sabiam que iam morrer (qualquer que fosse a representação que disso construíam) e também comunicavam uns com os outros, tinham segredos e malícia, copulavam e reproduziam-se não como animais, mas através desse "mais" (dessa fantasia que transforma a cópula "obscena" em ato cultural) que é essencial à reprodução humana, etc., etc. Nós sabemos que as suas vidas, a sua opacidade, permanecerá para

10. A pergunta que Cristo formula ao Pai na cruz é lancinante, terrível: “pai, por que me abandonaste?”. Sintetiza a nossa cultura. A religião cristã é a única em que dá origem a um verdadeiro ateísmo, porque na cruz, quem morre, é o próprio Deus, indissolúvel do filho. 
sempre na nossa interrogação: mas, nós como eles, somos seres sociais, que precisamos do Outro para nos constituirmos, somos seres da fala, da linguagem, e, como tal, somos seres da castração (tenhamos ou não consciência disso), no sentido que a psicanálise freudiano-lacaniana a caracterizou. Ou seja, viemos ao mundo indefesos, só crescemos e nos tornamos adultos dentro de uma comunidade, e portanto estamos imersos num universo simbólico e não apenas imaginário, somos falados pela linguagem materna, ou seja, mesmo quando exprimimos o que sentimos ser mais íntimo, estamos a falar a linguagem do Outro que aprendemos, exprimimo-nos pois a partir de uma "extimidade", isto é, de algo que Lacan conceptualizou ${ }^{11}$ e que rompe a dualidade exterior-interior; a nossa mais pretensa "intimidade" é um Outro para cada um de nós... quer tenhamos ou não consciência disso, lembro mais uma vez.

Portanto, sem que haja qualquer sentido em considerar a existência de uma "natureza humana", atemporal e supra-histórica, sabemos, quando nos acercamos de um sítio arqueológico, que ele é diferente de um outro local qualquer, que temos de o abordar com uma prevenção teórica e metodológica que tomba dentro da problemática das "ciências do espírito" ou da "cultura". Sabemos também que, ao contrário das outras espécies em geral, o ser humano é suscetível de se comportar de forma ambígua, polissémica, manhosa, calculada, isto é, cheia de sentidos e de subentendidos, e por consequência a realidade arqueológica igualmente tem de ser diversificada e com um tipo de complexidade próprio, que nos impede de projetar nela a nossa "filosofia espontânea”. E, muito menos, um funcionalismo chão do nosso senso comum. Todavia, essa ingenuidade permanece em alguns colegas, como sabemos, e temos de ter todo o cuidado na utilização de conclusões que eles tendem a apresentar como certas, precisamente quando se trata de questões mais desafiantes do nosso senso comum atual.

Como refere Julian Thomas no seu livro, estudar a modernidade (e a emergência da arqueologia científica que ela exigiu e possibilitou) põe-nos desde logo de sobreaviso sobre aquilo que somos ou julgamos ser, e portanto, dada a variabilidade humana, ficamos logo cientes daquilo que outros não pode-

11. V. por exemplo, Estimacy, de Jacques-Alain Miller, in https://www.lacan.com/symptom/extimity.html riam, em princípio, ser ou fazer. "Modernos" não eram com certeza; mesmo nós, segundo alguns, nunca o chegámos a ser (Latour ${ }^{12}$ ).

É preciso abordar a realidade arqueológica com distância, com sentido crítico e a "suspeita" que ela gera, mas ao mesmo tempo com a empatia de estarmos sempre dentro do campo das ciências sociais e humanas, e não no das ciências naturais, por mais que recorramos à colaboração aberta com os nossos colegas dessas áreas; todos temos muito a aprender uns com os outros, porque cada modo de conhecimento pode tornar-se um campo fechado, senão mesmo uma fortaleza bem defendida, com uma linguagem técnica idiossincrática e tudo, se não percebermos que ao menos o conhecimento não deveria, não deve, ser propriedade privada de ninguém.

Este é um ponto capital, que distingue as arqueologias ditas pós-processuais das processuais: a realidade arqueológica ("archaeological record"), com que nos confrontamos hoje, não se pode encarar como uma realidade natural, produto de fatores que agem ou agiram na "natureza", porque sobre ela sabemos, mesmo sendo apenas constituída por elementos "materiais", que é prenhe de sentidos "meaning(s)", palavra importante que aparece com frequência em Thomas e autores afins - especificamente humanos. Esses sentidos são-nos desconhecidos, é verdade, no seu aspeto específico; mas podemos sempre ter presente, pelo menos em termos de probabilidade, aquilo que não são, que nunca podiam ter significado para qualquer ser humano. É aqui que se instala uma espécie de "diálogo mudo" entre nós e o que encontramos. O conhecimento humano procede muito por descarte de teorias ou procedimentos que deixaram de ser úteis à nossa visão ou procedimento atuais; e também pode levantar hipóteses interpretativas mais ou menos verosímeis. Não podemos provar como cientificamente certa a hipótese a, b ou c; mas, apenas o formulá-la é uma forma de enriquecimento intelectual e de conhecimento, com base na experiência de observação direta. E podemos rejeitar como muito improváveis ou mesmo impossíveis (erradas) as hipóteses, digamos, $x, y$, ou z. Dou um exemplo: quando, em contexto fechado, selado intencionalmente, encontro um conjunto de fragmentos de vasos cerâmicos que não colam uns aos outros, que são relativamen-

12. Latour, Bruno (2007) - Nous N’Avons Jamais Été Modernes, Paris: La Découverte. 
te diferentes na pasta, cor, etc., e que têm fraturas muito antigas, isto é, que não só foram depositados nesse contexto já partidos, mas pertencem a recipientes diferentes, tenho de concluir, como muito provável, que essa foi uma deposição intencional de realidades parciais, que pelo facto de serem colocadas junto umas das outras, e "escondidas", significavam qualquer coisa de especial. Posso mesmo ir mais longe, quando esta mesma realidade, ou outras análogas (deposições fechadas de vários objetos já sem qualquer utilidade), se repete no mesmo sítio arqueológico: as pessoas que, numa certa altura, ou numa certa época geral datável, atuaram naquele local, atribuíam importância simbólica (no sentido vulgar de simbolismo) à junção num espaço diminuto e escondido de pedaços de objetos sem qualquer funcionalidade. Com conhecimento de outros sítios arqueológicos do mesmo tipo/época, e até da mesma região, e de informação de natureza etnológica oriunda de diversíssimos contextos, eu poderia escrever todo um livro só sobre as possíveis interpretações de tais deposições simbólicas escondidas. Mas refreio-me nessa solução fácil, e posso perguntar, no âmbito do local em estudo - penso por exemplo em Castanheiro do Vento (Horta do Douro, Vila Nova de Foz Côa $)^{13}$ e no sítio em parte análogo de Castelo Velho de Freixo de Numão na mesma zona ${ }^{14}$, a $11 \mathrm{~km}$ de distância em linha reta se tal sistema de deposições não existiria em todo o sítio, a diferentes escalas. De facto, durante as escavações daquele primeiro local (C. Vento), que já duram há mais de 20 anos, todo um conjunto de objetos "anómalos" (pela forma, aspeto, ou localização) foram encontrados, em diferentes posições. Não sendo este o local próprio, dou apenas dois exemplos, entre muitos. As principais estruturas que ali se encontram correspondem a embasamentos pétreos (de xisto, aglutinados por argila) de muros de terra; nesses embasamentos, ou no que deles resta, foram encontrados, no caso de um dos muretes, quantidades enormes de pequenos fragmentos de quartzo, de dimensão e forma repetitivas, cuja cor

13. Escavações atualmente dirigidas pelo autor, por João Muralha Cardoso, Ana Margarida Vale, e Sérgio Alexandre Gomes, mas por cuja direção já passaram outros arqueólogos, como Leonor Sousa Pereira, Gonçalo Leite Velho, Bárbara Carvalho.

14. Escavações dirigidas por Susana Soares Lopes, da FLUP, já concluídas há muito, e iniciadas em 1989. branca contrastava, no momento da sua exposição pelos trabalhos, com o alaranjado-acastanhado característico da argila local, ou a cor mais escura dos xistos e grauvaques. Esses elementos, brilhantes ao sol, não seriam visíveis após a construção terminada, nem tinham qualquer propósito funcional; estavam ali a sinalizar qualquer coisa, eram elementos simbólicos. ${ }^{15}$ Um outro aspeto, entre centenas, que nos chamou necessariamente a atenção, foi a deposição na vertical, ao longo de certos embasamentos, e próximo destes, de pedaços talhados de paredes de vasos cerâmicos de certa dimensão (como se fossem placas mais ou menos planas, e onde portanto a curvatura da pança não seria muito acentuada); usando uma expressão corrente, não serviam ali para nada; eram mais uma deposição simbólica.

Mas tudo isto só surpreende um espírito ingénuo, se pensarmos que, em todas as épocas e em muitas culturas, o maior esforço dos seres humanos que realizaram construções providas de certa durabilidade, se descontarmos as militares, se concentrou em "obras" que não tinham um qualquer préstimo, que não fosse precisamente simbólico, e hoje constituem grande parte do património histórico-cultural que queremos preservar e admirar. E porquê? Neste aspeto podemos arriscar uma afirmação geral. O ser humano - mau grado as ideias "continuistas", que negam a "exceção humana", e são de atroz simplismo - é totalmente diferente das outras espécies, uma vez que é dotado de autoconsciência e portanto também de inconsciente, sendo que a realidade lhe aparece como algo de inquietantemente estranho ("Unheimliche" na expressão de Freud ${ }^{16}$, que o inglês traduz por "uncanny"). Essa "estranheza" está ligada a todo o comportamento simbólico (no sentido corrente e não lacaniano da palavra) e, de um modo geral, ao imenso esforço (de conceptualização mas também de transformação e marcação física do espaço-tempo, frequentemente através da construção de locais ou outros espaços relacionados com

15. Uma vez, uma aluna chamou-me a atenção para uma área que estava a escavar e onde lhe aparecia, no mesmo nível e lado a lado, numa área restrita, uma certa quantidade de elementos de xisto, todos de cor e textura diferentes, acrescentando inteligentemente: "professor, está aqui todo um manual de geologia”. Descontando o exagero do seu entusiasmo, ela tinha razão: todo o sítio é um agregado de elementos ali depositados intencionalmente.

16. Cf., por exemplo https://pt.wikipedia.org/wiki/O_ inquietante (acedido em julho 2020). 
cultos religiosos) que todo o ser humano, desde pelo menos o que na Europa designamos Paleolítico superior, parece ter feito para dar um sentido ("meaning") ao mundo e à sua existência. Esse aspeto é fulcral, traduzindo-se em inúmeros sinais, desde o enterramento e culto dos defuntos, até às manifestações da chamada "arte rupestre", e, de um modo geral, à necessidade, por parte dos grupos ou comunidades, de demarcarem "culturalmente" o "natural”, desde o corpo (apondo-lhe transformações e signos de todo o tipo) até ao território, construindo aquilo que nós, com os olhos de hoje (os únicos, obviamente, com que podemos tentar compreender o Outro) podemos chamar "paisagens simbólicas", pontuadas por construções mais ou menos perenes, que sempre procuraram dar um sentido humano ao espaço. Sem entrar em detalhes, tudo se passa como se o ser humano, dotado da linguagem, ser da fala (que sempre "falha" na totalidade do que supostamente quereria dizer, comunicar; e portanto o ser humano é também um ser "falhado", barrado, como nos ensina a psicanálise lacaniana), não pudesse suportar a vacuidade de sentido com que o espaço e o tempo lhe aparecem na sua aparente continuidade, na sua estranha alteridade, precisando de os cindir, de os marcar, de os dividir com pontos de referência. Transforma assim os espaços naturais, através de uma variedade infinita de dispositivos e de formas, naquilo que poderíamos designar, com os olhos de hoje, "paisagens culturais, humanizadas", ou seja, ambientes dotados de significação, em que as comunidades se refletem e, ao mesmo tempo, se sentem por sua vez refletidas, na medida em que assim também se constituem identidades coletivas e memórias, povoadas de narrativas, efabulações, cenários de inúmeras vivências e inculcação de laços sociais, etc. Inculcações essas que se produziriam, desde logo, no momento da construção de tais dispositivos, sobretudo daqueles que requereriam imenso trabalho coletivo (como é o caso do já citado Castanheiro do Vento, na nossa linguagem atual uma "colina monumentalizada"), certa disciplina e concertação entre todos os executantes da "obra", incluindo os encarregados de a manter e de, eventualmente, lhe produzirem transformações.

Num texto recente, intitulado "A Arqueologia na encruzilhada dos saberes contemporâneos: uma perspetiva” (v. bibliografia) tentei resumidamente sintetizar, com base em diversos autores não arqueólogos, a minha visão atual da disciplina como um todo. Porque, tal como também o livro de Julian Thomas nos mostra, só de fora da arqueologia (como de qualquer outro saber) se pode ter dela uma visão distanciada e crítica, relacionada com o conjunto do saber contemporâneo. Claro que a inter e a transdisciplinaridade só se conseguem a partir de um certo amadurecimento interno de cada disciplina; e por isso a luta da minha geração, pelo menos em Portugal, foi a independentização da arqueologia como disciplina e prática adultas, tanto ao nível da investigação, como do seu ensino, como da sua administração pública, central e local. Dada a tradicional vinculação à história, era crucial separar as duas disciplinas, no sentido de impedir que a arqueologia continuasse a ser "ciência auxiliar" de qualquer outra. Isso foi um passo em frente, como já tinha sido, muito antes, a desvinculação da arqueologia em relação à arquitetura: lembremo-nos por exemplo de que a centenária Associação dos Arqueólogos Portugueses se começou por designar "Real Associação dos Arquitetos Civis e Arqueólogos Portugueses.” Este ponto é importante, porque tem a ver com o estatuto da realidade arqueológica, a que muitos continuam a chamar "registo arqueológico", e que Julian Thomas comenta em vários pontos do seu livro, nomeadamente a pp. 210 e seguintes, quando se refere às posições de Childe e de Binford. Trata-se de saber se as "coisas materiais" com que a arqueologia se confronta têm "sentido" ("meaning"), isto é, podem ser interpretadas como resultado de ações pretéritas: para Childe, só depois de passaram pelo crivo da classificação e tipologia; para Binford, tais realidades só poderão eventualmente ter sentido depois de filtradas por todos os modernos processos de estudo das ciências naturais a elas aplicáveis. Ora, a forma de encarar a arqueologia não é independente da área específica de estudo de cada autor: Childe foi um pré-historiador histórico-cultural que entroncou essa visão com uma forma de evolucionismo e de marxismo; Binford estudou sobretudo caçadores-recolectores, e pertence a um mundo académico norte-americano onde arqueologia e antropologia (incluindo a "física") se imbricam, e está muito influenciado pelo "espírito" das ciências naturais. Um arqueólogo da época romana, da Idade Média, da época moderna ou contemporânea, mais ou menos provido de documentos escritos, tem de ter uma perspetiva completamente diferente, histórica, do arqueólogo da pré-história que, por não ter tais documentos (e, muitas vezes, a "ilusão de sa- 
ber” que eles conferem...) se vê confrontado apenas com a mudez da "matéria" bruta, para acentuarmos o contraste. "Bruta" não será de facto a palavra mais adequada, porque numerosos estudos antropológicos nos advertem para uma série de aspetos que nunca podemos aplicar a sociedades pré-modernas. Inúmeras observações apontam para ontologias de povos contemporâneos estudados pela antropologia em que de modo algum as rochas, os sedimentos, os elementos vegetais, a água, etc., não eram apenas encarados como elementos materiais ou "matérias-primas", isto é, como matéria mais ou menos inerte que o ser humano usava nas suas obras, conferindo-lhes "sentido". Humanidade e natureza não estão separadas uma da outra como no naturalismo racionalista europeu que começa a emergir no século XVI; antes, o ser humano está imerso num mundo de que faz parte intrínseca, mundo esse povoado de sentidos que ele tem por si mesmo, e que não lhe são conferidos, ou impostos, pelo ser humano. Isto não quer dizer que possamos aplicar à pré-história uma ontologista animista como Philippe Descola caracterizou na Amazónia, ou uma cosmologia totemista como ocorria na Austrália antes de ser invadida por europeus, ou mesmo uma visão analogista do mundo, muito espalhada, incluindo no próprio Ocidente, antes do racionalismo moderno (Descola, 2005). Mas pelo menos significa descentrar a nossa cultura moderna de ocidentais relativamente a outras possibilidades ontológicas, mostrando como o modo de interpretar em pré-história tem de ter regras muito flexíveis, muito diversificadas, e proceder com uma prudência que frequentemente perdemos de vista. Nós, arqueólogos, e em particular estudiosos da pré-história como aquele que escreve, não podemos apenas circunscrever-nos a toda a tecnologia hoje ao nosso dispor; temos, para além dela, de estar atentos ao debate cultural e científico contemporâneo ${ }^{17}$, antropológico, sociológico, etc. - filosófico em última análise - para não cairmos na pobre rotina de, acrescentando novidades e descobertas, por vezes sensacionais, nos movermos sempre dentro da mesma redoma, na nossa zona de conforto doméstico. Porque assim repetimos, no essencial, ba-

17. Veja-se, por exemplo, o excelente e esclarecedor debate entre dois "gigantes" da antropologia atual, Tim Ingold (numa linha vitalista, mas original) e Philippe Descola (numa linha estruturalista, como continuador do grande Lévi-Strauss): Être au Monde..., 2014 (v. bibliografia). nalidades discursivas, "déjà vus" interpretativos, confrangedoras redações que até podem ter ressonância poética, mas nada acrescentam de um ponto de vista realmente crítico, racional, científico em suma. É claro que tanto Gordon Childe, como Leroi-Gourhan, como Claude Lévi-Strauss, como Jean Guilaine, como Lewis Binford, como Ian Hodder, como Michael Shanks, entre muitos outros, nos ajudaram sempre a ver "paisagens conceptuais” novas, e por vezes muito poderosas. Nunca estarão esgotados, como o próprio Julian Thomas, que sempre nos traz, precisamente, inspiradores pensamentos, incitações para refletirmos. Mas as novas gerações, aos ombros desses gigantes, terão agora de construir arquiteturas disciplinares próprias, adaptadas a cada submundo da arqueologia, e não confundindo abertura com importação acrítica de ideias que, parecendo fascinantes, ou virem ao encontro dos nossos problemas interpretativos - penso, por exemplo, nos "novos materialismos", que começam a fascinar alguns jovens - ainda mais nos afastam deles. Não advogo assim uma teoria geral para a arqueologia, pois creio que isso não tem sentido, nem acontece noutras ciências. Há, quando muito, e na época atual de tantas incertezas, teorias "regionais" mais ou menos úteis para este ou aquele domínio, as quais deverão estar constantemente sujeitas à crítica e ao debate informado. Claro que nada disto acontecerá se o ensino universitário continuar a degradar-se e, paralelamente, se a arqueologia for abandonada como disciplina menor, sem meios para a pesquisa de fundo, e apenas útil para "reconstituir" certos sítios como pontos de interesse turístico, num quadro de crise geral societária. Quer dizer, no modelo de sociedade em que nos encontramos nunca poderemos ir muito longe; apenas, e com algumas exceções, continuar a realizar trabalhos pontuais para fazer "prova de vida"; por isso, quem possa ainda alertar para este estado de coisas tem absoluta obrigação ética de o fazer.

Voltando ao livro de Julian Thomas que nos serve de "rampa" para debater algumas ideias sobre arqueologia, não há dúvida de que é uma obra excelente. Os dois primeiros capítulos são sínteses bem conseguidas para caracterizar a emergência da Modernidade (cap. 1) e o papel da arqueologia nascente nas tensões que a modernidade gerou (cap. 2). Tenho o meu exemplar todo sublinhado a várias cores, numa óbvia estratigrafia de leituras e de entusiasmos; gostaria porém de comentar sucintamente alguns pon- 
tos. Na pág. 1, diz-se que o passado nunca se revela inteiramente a nós; pelo que atrás referi, penso que essa afirmação era escusada; na pág. 4, parece sugerir-se que remotas "escavações" ainda não eram arqueologia, mas se dirigiam a realidades arqueológicas; no meu entender, não, não era assim, as realidades arqueológicas foram criadas pela arqueologia, na Modernidade como Thomas tão bem explica, e não pré-existiram, em embrião, a essa nossa época; na pág. 15, relativamente aos gabinetes de antiguidades como teatros de memória (uma boa caracterização) diz-se serem alheios ao atual museu...bem, o museu é uma realidade que explodiu em tantas direções e se liga com tantas outras coisas, incluindo a encenação de memórias, que não sei se se pode ser tão afirmativo assim... Nas págs. 47,48 e 50 parece escamotear-se a evidência de que tanto a $\mathrm{I}^{\mathrm{a}}$ como a $2^{\underline{a}}$ guerras mundiais foram afrontamentos de escala inaudita entre potências capitalistas, na luta pela supremacia de oligarquias, que não recuaram perante nada, e nisso estou de acordo com Bauman, citado pelo próprio Julian Thomas (p. 49), segundo o qual que o nazismo (bem como aliás todos os fascismos, o italiano, o espanhol, o português, e por aí adiante...) foram produtos típicos da Modernidade (aos quais aliás poderíamos juntar o próprio estalinismo, e por aí fora....). ${ }^{18} \mathrm{~A}$ Modernidade trouxe-nos aquilo que Arendt designou "banalidade do mal". ${ }^{19}$

O cap. 3 do livro tem um título que entendo menos bem: "A tirania do método". Logicamente, trata-se de descrever metodologias em relação às quais o autor, influenciado por Heidegger (v. p. 59, por ex.), tem uma posição de discordância, com a qual basicamente estou de acordo, embora eu não assuma o anti-cartesianismo que Thomas partilha; Descartes

18. Aliás, a realidade globalizada que hoje vivemos, na sua extrema violência e desumanidade trágicas, não se pode entender fora da estratégia capitalista neoliberal, que todos os países e todas as esferas de ação contaminou: a busca de lucro sobrepôs-se a qualquer racionalidade e a qualquer moralidade, que chegam a assumir formas extremas, verdadeiramente circenses (chefes de estado eleitos que se comportam como palhaços; mafias que tomaram conta da realidade de bastantes países), desbragadas, sem entraves, numa manifestação agonística de que o sistema do lucro é total, assumida e orgulhosamente obsceno. Encena-se em público, sem vergonha. É um circo, sim, mas mortífero.

19. V. por exemplo sobre o assunto a tese de Diniz, Nádia Souki (2008) - Hannah Arendt e a Banalidade do Mal, Minas Gerais: Universidade Federal de Minas Gerais. foi crucial no seu tempo, e é óbvio que temos de recolher o que de útil nos deixou, situando-o num momento particularmente frutuoso da história do pensamento. Claro que a realidade arqueológica não nos aparece sob a forma de uma qualquer "materialidade" a que teríamos depois de conferir "sentido". Qualquer elemento da realidade, da "substância" que o sujeito vê, nomeia, e pretende entender, está desde logo mediada por esse mesmo sujeito e por toda a "bagagem" que traz consigo. Esse conceito de mediação (hegeliana) é fundamental, para entendermos dialeticamente a nossa relação dialética com o Outro, incluindo tudo, nomeadamente as chamadas "coisas materiais". Em arqueologia, naturalmente, tal mediação é metodologicamente orienta$\mathrm{da}$, como em qualquer trabalho científico, segundo os métodos e os pré-conceitos de cada época/escola. E portanto a "distinção absoluta entre objeto e sujeito" de que fala Thomas na p.77 não é limitativa, se em vez de a tomarmos rigidamente, introduzirmos a mediação subjetiva que está sempre presente (e é produto em arqueologia de uma "negociação" de equipa) entre nós e a realidade. Porque obviamente no trabalho de campo, por exemplo, sendo uma tarefa coletiva, nada do que aí ocorre deixa de passar por esta triangulação: o que lá está no terreno, os métodos consensualizados pela equipa dirigente, e a subjetividade desta e de cada um dos seus membros. Claro que a orientação dos trabalhos e as conclusões que dele resultam implicam sempre, em cada momento, esta dialética; nós estamos sempre a fazer escolhas, nomeadamente entre estratégias a seguir, e por isso o mesmo sítio, se idealmente fosse passível de ser estudado por duas equipas diferentes, forneceria com certeza realidades (mais ou menos) diferentes. Se a realidade em geral não é totalizável, se ela é não-Toda, a nossa posição de investigadores também o é, por mais esforços que devamos fazer no sentido de reduzirmos aqueles elementos de subjetividade que prejudiquem o entendimento de colegas, presentes ou futuros. É a isto que chamamos objetividade: não a revelação/resolução "matemática" de fórmulas indiscutíveis dentro da sua lógica específica (as quais têm o seu lugar próprio), mas uma disposição e prática de rigor sempre em afinação, e onde a intuição, a perspicácia, toda a bagagem cultural de uma equipa, enfim, entram em linha de conta decisiva. Por isso uma escavação é também performativa, um evento único, levado a cabo por pessoas concretas, dotadas de meios concretos, 
e não uma experimentação laboratorial quando esta é totalmente sujeita a um algoritmo mais rígido. E isto aplica-se a todo o "processo arqueológico", desde o princípio ao fim de um projeto: sempre obra de sujeitos concretos, procurando, porque investidos de uma responsabilidade pública, ser o mais rigorosos possível perante uma realidade que vão alterando à medida que a observam, e que portanto, longe de ser uma realidade estática ou morta, é sempre dinâmica e mediada pela atividade intencional e até afetiva (na medida em que nela ressoam necessariamente afetos; nós não somos robôs) dos que com ela se confrontam.

Os capítulos 4, 5 e 6 do livro são também excelentes. Claro que, como escreve o autor na pág. 144, “(...) nós nunca podemos entrar na vida mental de uma pessoa do passado (...)", mesmo que seja o Homem do Gelo encontrado congelado nos Alpes. Nós, cada um de nós, não podemos nunca "entrar" na vida mental do Outro, presente ou pretérito; e por isso é que o Outro, sendo para nós essencial (nenhum sujeito se constitui sozinho, como também evidentemente refere Thomas) é ao mesmo tempo um "eterno enigma"; mas, como a psicanálise lacaniana nos ensina, ele é também um enigma para si mesmo. ${ }^{20} \mathrm{Na}$ pág. seguinte, Thomas refere que "as arqueologias do indivíduo não nos dão uma teoria do sujeito (...)"; ora, claro, não dão nem podiam dar partindo dos pressupostos simplistas de que partem. Esta consideração também se aplica ao exposto na pág. seguinte (147). Não é preciso lembrar que o problema do sujeito - central na Modernidade, pelo menos desde, precisamente, Descartes - é um problema antiquíssimo da filosofia...e para a discussão do qual os contributos da psicanálise lacaniana, no âmbito filosófico, são incontornáveis: basta ver a complexidade imensa da filosofia žižekiana (entre muitas) a esse respeito ${ }^{21}$, a qual desde 1989 se vem impondo mundialmente; pode a arqueologia passar ao lado dela e de tantas outras que com ela dialogam ou se confrontam? Claro que não.

Quanto ao cap.7, tão interessante, é pena que se quede em Freud, que não vá um pouco além das perspe-

20. V. por exemplo o meu capítulo contendo um resumido comentário do grafo do desejo, de Lacan, em: https://ler. letras.up.pt/uploads/ficheiros/18125.pdf

21. Cf. por exemplo o livro recente de Žižek, Slavoj (2019), Sex and the Failed Absolute, Londres: Bloomsbury Academic. tivas que este grande autor há um século nos deixou. De facto, neste capítulo consagrado à relações entre profundidades e superfícies que têm constituído uma das preocupações do pensamento moderno, Julian Thomas aborda o paralelismo das noções de Freud como fundador da psicanálise com aquelas em que também se baseia a arqueologia, nomeadamente no que toca à importância, real ou metafórica, dada à dicotomia superfície-profundidade que, segundo ele, preside a ambas as disciplinas (bem como, repito, a muitas outras áreas do saber filhas da Modernidade). Seria na profundidade do solo, do que se não vê à vista desarmada antes da escavação, como na "profundidade da psique", que se não revela senão em sonhos, atos falhados, lapsos de linguagem, etc., que tanto Freud como os autores seus contemporâneos, nomeadamente os arqueólogos, veriam a "verdade" da realidade, que se mostra de forma enganadora à superfície. Esta dialética profundidade-superfície, típica da Modernidade, é aqui acentuada de justa forma por Julian Thomas. Posteriormente, em artigo intitulado "Sigmund Freud's archaeological metaphor and archaeology's self-understanding" (ver bibliografia), o autor aprofunda e desenvolve os pontos de ligação entre as duas disciplinas no momento do nascimento da psicanálise e no de maturação da arqueologia, que podemos situar convencionalmente a partir do início do século XX. E escreve (p. 62) que “A arqueologia e a psicanálise têm uma longa história em comum e (...) isso é também uma plataforma para futuros desenvolvimentos que se podem revelar enriquecedores para nós todos. Assim como as mais recentes formas de psicanálise podem ser úteis à arqueologia, pode dar-se o caso de que um entendimento transformado da arqueologia e suas práticas possa ajudar a psicanálise a reavaliar as sua própria história." ${ }^{22}$ No fim deste capítulo, Thomas faz uma

\footnotetext{
22. Assim, o autor toca aqui num ponto que me vem interessando muito desde 2006, altura em que, por via de ter "descoberto" Slavoj Žižek, fui de novo recuperar uma antiga curiosidade (vinda dos tempos estruturalistas) por Jacques Lacan, autor que tenho andado a estudar. De facto, como Julian Thomas sabe, a psicanálise, longe de ter parado em Freud, o seu criador, teve imensas repercussões e desenvolvimentos, sendo indispensável para compreender, por exemplo, o pensamento francês de todo o século XX e, em geral, o pensamento contemporâneo. Ora, na linha de raciocínio de Thomas, ou seja, de que a arqueologia não existe numa ilha, mas o seu aparecimento e desenvolvimento se liga intimamente a todo o pensamento moderno e contem-
} 
importante advertência, ao escrever (p. 17o) que uma “(...) visão essencialista do passado poderia ser comparada com a visão pós-cartesiana da mente, bem escondida no interior da pessoa. Do mesmo modo, é inútil imaginar que o passado é uma substância que está oculta em sítios obscuros aguardando ser posta à luz. Os vestígios do passado estão todos à nossa volta, e nós habitamos o passado em importantes sentidos." Não poderia estar mais de acordo; aliás, a própria psicanálise lacaniana, que esteve sempre em reformulação constante, de acordo com a evolução teórica e a prática crítica do autor (uma articulação dinâmica teoria/prática que também encontramos em arqueologia, como em múltiplos saberes), "desmedicamentalizou" muito Freud e alterou as suas tópicas. Por exemplo, a noção de inconsciente de Freud foi profundamente reformulada, mantida como uma simples "ficção útil", bastando atentar em dois célebres aforismos de Lacan, mil vezes repetidos por ele e outros, em milhares de escritos, para se ver como a questão, que não posso desenvolver aqui, foi totalmente alterada e complexificada: "o inconsciente está estruturado como uma linguagem" e "o inconsciente é o discurso do outro". A obra de Lacan aponta para um universo de sentido completamente diferente do de Freud ${ }^{23}$, mas muito útil - para não

porâneo, penso que se pode prolongar utilmente o contributo de Thomas no sentido de mostrar que não só a arqueologia contemporânea, mas toda a cultura dos nossos dias não pode passar sem os desenvolvimentos da psicanálise, e em particular sobre o ensino de Lacan e seus seguidores. Não se trata de incensar Lacan, tanto mais que a sua obra esteve sempre em renovação... Lacan pensava, provavelmente com razão, que a sua grande descoberta teria sido o "objecto pequeno a" (o objecto causa do desejo)... ora bem, esse último Lacan - com a importância dada ao Real no conjunto do seu nó borromeano, Real esse de que o pequeno a (a com letra pequena, de autre em francês, por referência a Autre, o grande Outro) é um resto, mas um resto crucial esse último Lacan, dizia, é indispensável para se compreender o nosso presente e, claro, também a nossa arqueologia, que evidentemente lida com o aqui e o agora em que nos encontramos imersos.

23. Apesar dele ter sempre dito aos que o ouviam, "sejam freudianos, e não lacanianos”, e sempre ter considerado a sua obra como um retorno a Freud (para a desviar dos imensos desvirtuamentos que sofreu, gravíssimos, particularmente no meio anglo-saxónico e especialmente norte-americano, em que a psicanálise foi totalmente subvertida no pior sentido, o de um reforço da psicologia do ego), esse retorno, essa repetição se quisermos, fez de Lacan um dos maiores pensadores originais do século XX. A melhor continuidade que se pode dar a um "inspirador" é tomar como obrigação repensá-lo, transformá-lo, atualizá-lo. dizer indispensável - à compreensão do humano e portanto da arqueologia também (v. por exemplo Chieza, 2007 ${ }^{24}$ ).

Não me sobra praticamente espaço para comentar devidamente os capítulos 8 (Mente, Perceção e Conhecimento), 9 (Materialidades) e 10 (Para uma Arqueologia Contra-moderna), mas creio que o que deixei dito ou sugerido antes talvez colmate em parte essa lacuna. Apenas posso dizer que, apesar de tudo, e do que conheço, estou muito mais do lado de Heidegger (o inspirador filosófico de J. Thomas) do que da filosofia da mente e do cognitivismo, muito mais do lado da teorização que sobre a experiência humana vem desenvolvendo um antropólogo como Tim Ingold do que da vertente "cognitiva" da arqueologia processual pela qual enveredaram autores como Colin Renfrew ou Steven Mithen (este último chegou a escrever um livro intitulado The Prehistory of the Mind, em 1996, Londres: Thames and Hudson), etc. Mas também me afastei, desde que tive tempo para estudar mais, de certo relativismo pós-moderno que afeta muita da arqueologia pós-processual. A arqueologia vive uma crise que acompanha a crise social neoliberal, e que a leva a ser atraída por novas ideias emergentes, como as de DeLanda, Graham Harman, e que atingem possivelmente o seu cúmulo com Jane Bennett e a sua noção de "matéria vibrante". Não, situo-me antes na linha da "escola de Liubliana" (Žižek, Mladen Dolar, Alenka Zupančič) e muitos outros autores que trabalham nesta linha, e estou convencido de que é por vezes nas épocas de maior crise e transformação social (como foi a da transição do século XVIII para o XIX, à qual devemos um Kant e todos os restantes que culminaram num dos mais notáveis autores do espírito humano, Hegel). É a Hegel que temos de voltar, penso eu (e estou bem acompanhado...), tomando em consideração no nosso domínio das ciências sociais e humanas, a que a arqueologia pertence, colegas de grande vulto, quer na antropologia (como Tim Ingold) quer na arqueologia (como Julian Thomas), e partir de um diálogo crítico e informado com esses autores, que me merecem respeito e confiança, mesmo na discordância, para construir novas filosofias (ou teorias, como se quiser) da arqueologia pré-histórica.

Ao seguir este caminho, tudo o que desejo é firmá-lo

24. Um livro que integralmente traduzi para a língua portuguesa (tradução inédita). 
bem, através de estudo continuado, para poder um dia, se a vida me deixar tempo e ânimo, escrever algo que possa ombrear com o esforço daqueles meus amigos e mestres. No entretanto, aconselho todos os meus colegas portugueses a lerem e relerem "Archaeology and Modernity", que aqui me serviu de pretexto de pensamento, e que é ainda, como todas as obras inteligentes, um livro inspirador.

Loures, julho de 2020

\section{BIBLIOGRAFIA}

CHIEZA, Lorenzo (2007) - Subjectivity and Otherness: a Philosophical Reading of Lacan, Cambridge-Massachusetts: MIT Press.

DESCOLA, Philippe (2005) - Par-Delà Nature et Culture, Paris: Gallimard.

DESCOLA, Philippe; INGOLD, Tim; LUSSAULT, Michel (2014)-Être au Monde: Quelle Expérience Commune?, Lyon: Presses Universitaires de Lyon.

FOUCAULT, Michel (2005) - As Palavras e as Coisas. Uma Arqueologia das Ciências Humanas, Lisboa: Ed. 70.

FOUCAULT, Michel (2005) - A Arqueologia do Saber, Coimbra: Almedina.

FOUCAULT, Michel (2005) - Naissance de la Clinique, Paris: Presses Universitaires de France.

JAMESON, Fredric (1991) - Postmodernism or, The Cultural Logic of Late Capitalism, London: Verso.

INGOLD, Tim (2015) - Estar Vivo: Ensaios sobre Movimento, Conhecimento e Descrição, Petrópolis: Editora Vozes.

LACAN, Jacques (2014) - Séminaire - XI - Les Quatre Concepts Fondamentaux de la Psychanalyse, Paris: Les Éditions du Seuil.

JORGE, Vítor Oliveira (2020) - Como se Faz um "Eu". Retornando sucintamente ao problema da constituição do sujeito e da subjetividade, in Jorge, Vítor Oliveira, coord. Modos de Fazer/Ways of Making [ebook], Porto: CITCEM, pp. 267-283.

JORGE, Vítor Oliveira (2020) - A Arqueologia na encruzilhada dos saberes contemporâneos: uma perspetiva, Conferência de encerramento do TAG ibérico 2020, organizado pela UNIARQ/FLUP e pela AAP, fevereiro 2020, Lisboa [inédito, consultável: https://www.academia.edu/ 43533673/A_Arqueologia_na_encruzilhada_dos_saberes_ contemporâneos_uma_perspetiva]

THOMAS, Julian (1996) - Time, Culture and Identity, Londres: Routledge.
THOMAS, Julian (2004) - Archaeology and Modernity, Londres: Routledge.

THOMAS, Julian (2004) - Archaeology's place in Modernity, in MODERNISM/modernity, vol. 11, number one, pp. $17-34$.

THOMAS, Julian (2009) - Sigmund Freud's Archaeological metaphor and archaeology's self-understanding, in Holtorf, Cornelius; Piccini, Angela, eds. - Contemporary Archaeologies: Excavating Now, Londres, Peter Lang, pp. 33-45.

ŽIŽEK, Slavoj (2009) - O Sujeito Incómodo. O Centro Ausente da Ontologia Política, Lisboa: Relógio d’ Água.

ŽIŽEK, Slavoj (2015) - Moins Que Rien: Hegel et l'Ombre du Matérialisme Dialectique, Paris: Fayard. 


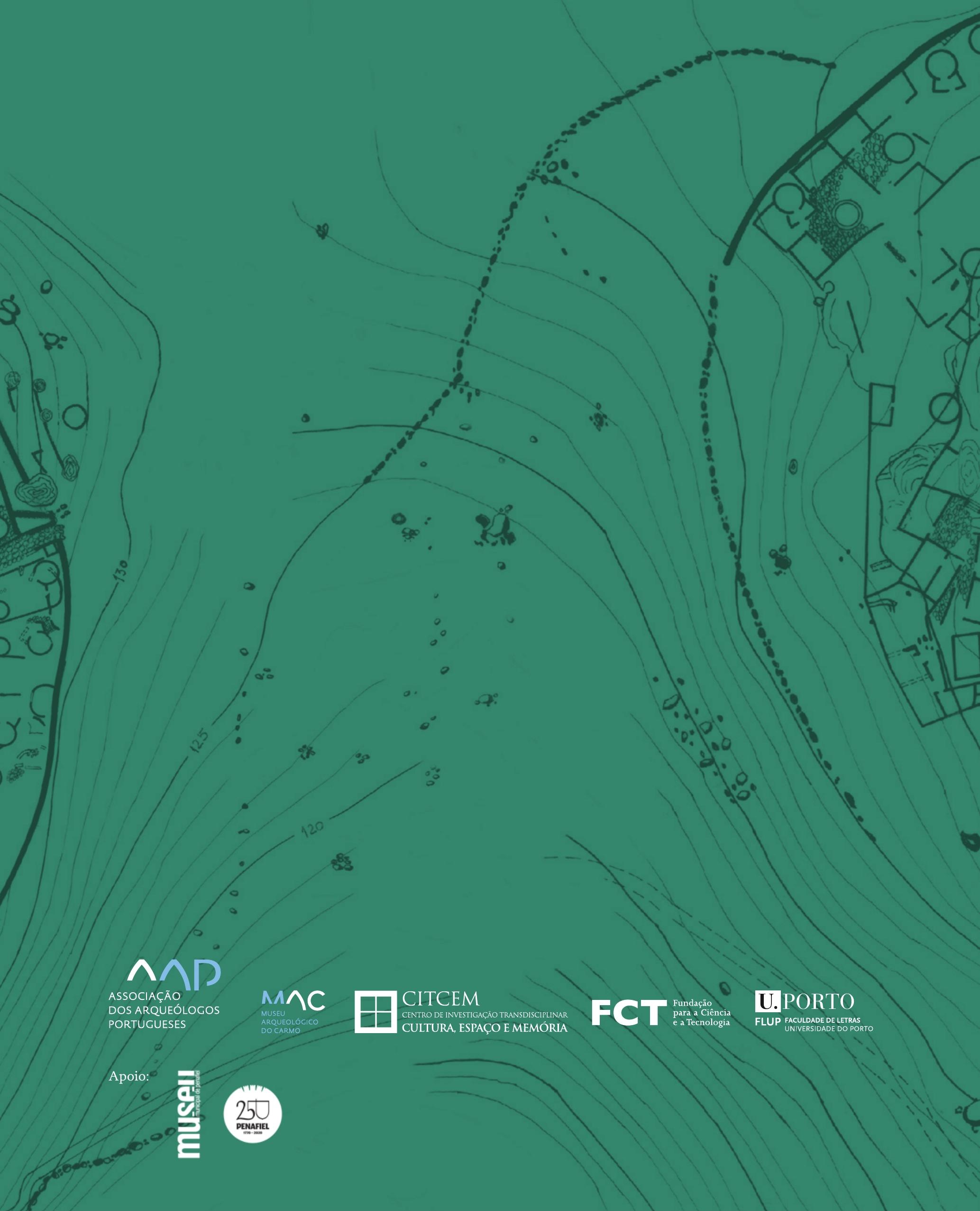

